\title{
Comparison of waste-to-energy technologies of gasification and incineration using life cycle assessment: Case studies in Finland, France and China
}

\author{
Jun Dong a, b, *, Yuanjun Tang a, b, Ange Nzihou ${ }^{\text {a }}$, Yong Chi ${ }^{\text {b }}$, Elsa Weiss-Hortala ${ }^{\text {a }}$, \\ Mingjiang $\mathrm{Ni}^{\mathrm{b}}$, Zhaozhi Zhou ${ }^{\mathrm{b}}$ \\ ${ }^{a}$ Centre RAPSODEE, Ecole des Mines Albi, Campus Jarlard, 81013 Albi Cedex, France \\ ${ }^{\mathrm{b}}$ State Key Laboratory of Clean Energy Utilization, Zhejiang University, Hangzhou, China
}

\section{A R T I C L E I N F O}

\section{Article history:}

Received 12 December 2017

Received in revised form

20 June 2018

Accepted 14 August 2018

Available online 24 August 2018

Keywords:

Municipal solid waste

Waste-to-Energy technologies

Life cycle assessment

Incineration

Gasification

Environmental impacts

\begin{abstract}
A B S T R A C T
Waste-to-Energy (WtE) has gradually constituted one of the most important options to achieve energy recovery from municipal solid waste (MSW). However, the environmental sustainability of a specific WtE system varies with used technologies and geographic differences. As a result, three representative WtE systems are compared using life cycle assessment (LCA): a gasification-based WtE plant in Finland, mechanical-grate incineration in France, and circulating fluidized bed incineration in China. Results show that the overall environmental performance of the gasification system is better than incineration. The use of gasification technology, attributed to an intermediate syngas purification step, can provide benefits of both reducing the stack emissions and increasing the energy efficiency. Regional waste management, especially related to MSW caloric value and emission regulation, are determining factors for a preferable performance of the incineration in France over that in China. Sensitivity and uncertainty analyses further address key variations such as choice of MSW composition, basis of displaced electricity, energy recovery mode, and application of "best-available technology" dedicated to incineration. It is found that the most sensitive parameters influencing the LCA results are: electricity recovery, $\mathrm{CO}_{2}$ emission, and $\mathrm{NO}_{\mathrm{x}}$ emission. In the future, use of the source-separated high caloric waste combined with a more stringent emission standard can efficiently improve MSW incineration in China. Bottom ash recycling for metals and materials is highly applicable regarding incineration in France. This presented study can overall contribute to the development of specific WtE technology and local waste management plan for decision-makers.
\end{abstract}

๑) 2018 Elsevier Ltd. All rights reserved.

\section{Introduction}

The threat of global climate change and resource depletion become a driving force for changes in municipal solid waste (MSW) management towards a more integrated one. The waste hierarchy has been regulated (Directive Waste Framework, 2006; The European Parliament and the Council of European Communities, 2008), aiming at diverting MSW towards reduce, reuse and recycling. Landfill has the lowest priority because of the production of leachate and gaseous emissions, coupled with the pressure from

\footnotetext{
* Corresponding author. Centre RAPSODEE, Ecole des Mines Albi, Campus Jarlard, 81013 Albi Cedex, France.

E-mail address: zd_dongjun@zju.edu.cn (J. Dong).
}

land scarcity. Waste-to-Energy (WtE) technologies, consisting of mainly incineration, pyrolysis and gasification, take an inalienable role in integrated waste management attributed to significant waste mass and volume reduction, complete disinfection, and energy recovery from unrecyclable materials (Arena, 2012).

Currently the most mature WtE technology used worldwide is incineration. Statistical data have reported a steadily increased number of incineration plants: 455 plants were in operation in Europe in 2012 (Lausselet et al., 2016); while that number had increased 3.5-folds in China from 54 plants in 2004 to 188 plants in 2014 (Mian et al., 2016). The feedstock can be either the residual waste (i.e. the waste left over after separate collection) or pretreated feed, for example Solid Refuse Fuels (SRF) (Lombardi et al., 2015). However, despite the evolution of modern incineration technology that has notably reduced its environmental 
impacts, incinerators still face fierce opposition by the public owing to potential health risk, for example PCDD/Fs (Phillips et al., 2014). In this sense, there is considerable interest in WtE options based on pyrolysis and gasification. Pyrolysis/gasification-based WtE refers to a pre-stage of MSW thermochemical decomposition to generate combustible gas (named syngas), which is then linked to a downstream combustion process for energy recovery, named, "two-step oxidation". In comparison with direct incineration, syngas combustion may be more environmental-friendly and efficient. The potential advantages are also associated with lower $\mathrm{NO}_{\mathrm{x}}$ and PCDD/ Fs as a result of reducing atmosphere, reduced excess air and much easier emission control (Arena, 2012). Although being a relatively new concept, today the industrial application of pyrolysis/ gasification-based WtE starts to be organized. Around 100 plants have been reported in operation (Panepinto et al., 2015): they are generally based on gasification; the majority is located in Japan, with some applications operated in Europe. However, using newly developed WtE technologies do not imply an absolute environmental sustainability. By dividing a combustion process into two steps, the configuration of the whole plant tends to be more complex, which can lead to changes in the overall efficiency and environmental profile. Besides, pyrolysis and gasification processes essentially requires stricter feedstock pre-treatment (Shehzad et al., 2016); the making of which is energy intensive. This is accompanied by an unclear economic feasibility of pyrolysis/gasificationbased WtE while it is likely that more complex processes are cost intensive. Therefore, a comprehensive comparison of the environmental benefits and drawbacks of different WtE technologies is necessary for their appropriate implementation and development.

On the other hand, in addition to the differences associated with technology, the performance of waste systems is also highly dependent on geographic aspects, such as MSW composition, energy structure, and related information (Astrup et al., 2015; Bisinella et al., 2017; McDougall et al., 2008). The characteristics of MSW vary significantly worldwide, for instance, a higher proportion of paper (newspapers and packages) in Europe and a more important fraction of organic in Asian countries such as China, India and Thailand (Cardoen et al., 2015a, b; Hoornweg and Bhada-Tata, 2012; Laohalidanond et al., 2015). Consulting WtE applications, mechanical-grate (MG) incinerators occupy the majority share of the market around the world (Lu et al., 2017). While fluidized bed (FB) incinerators are less employed in Europe, they experience a much higher capacity percentage in Asian countries especially China (28.9\% in China, 2015 vs. $4.5 \%$ in Europe, 2013), owing to the appealing characteristics to treat high-moisture MSW (Chen and Christensen, 2010). As a consequence, the local MSW and operation conditions must also be factored in when developing effective WtE practices.

The above-mentioned technical and geographic aspects provide no simple guidance for selecting the best WtE technology. For this reason, a support tool for proper evaluation the holistic environmental impact across different MSW systems is essential. Life cycle assessment (LCA) is suitable to be severed as such methodology, which considers the entire life cycle of a product or service from cradle to grave, i.e., from raw material acquisition through production, use, and disposal. In fact, the growing importance of LCA applied in integrated waste management systems has been well recognized in recent years (Astrup et al., 2015; Bakas et al., 2018; Singh et al., 2013). A number of studies have been reported including the comparison of available treatment alternatives (landfill, incineration, composting, etc.) (Al-Salem et al., 2014; Evangelisti et al., 2014; Nabavi-Pelesaraei et al., 2017), and, evaluation of existing and potential waste management systems for regional waste strategy support and planning (Coelho and Lange, 2018; Ikhlayel, 2018; Yay, 2015). The choice of attributional or consequential LCA has been extensively discussed to address multifunctional processes such as recovered energy and commodities from waste management, which is still a source of controversy in LCA leading to different results (Brander, 2017; Finnveden et al., 2009; Laurent et al., 2014). Recent advances in LCA also attempt to incorporate hybrid models such as input-output analysis (IOA) (Rocco et al., 2017; Tisserant et al., 2017), material flow analysis (MFA) (Sevigné-Itoiz et al., 2015; Turner et al., 2016) to deal with complex waste management systems.

However, systematic assessment of different WtE technologies is still quite lacking other than incineration due to continuous development in new technologies. While this situation has stimulated a growing research interest during the last years (Al-Salem et al., 2014; Arena et al., 2015a; Evangelisti et al., 2015; Tan et al., 2015; Wang et al., 2015; Zaman, 2013), there is still no consistent consensus among the few existing LCA studies. For instance, by comparing three pyrolysis/gasification WtE (gasification-plasma, pyrolysis-combustion, and gasification-combustion), Evangelisti et al. (2015) found that only gasification-plasma system would be preferable than the modern incineration; while the study of Zaman (2013) indicated a superior performance of pyrolysis-gasification WtE (without plasma) over incineration seemingly based on a similar technology. This opposite result is seen to be primarily dependent on the energy recovery efficiency adopted. Al-Salem et al. (2014) investigated low temperature pyrolysis as alternative for waste management; however the feedstock considered plastic waste only. Also the existing works are often insufficient to address the differences in local waste characteristics and operation status (Bisinella et al., 2017).

Accordingly, this study aims to provide a LCA comparison of the environmental performance of both incineration- and gasificationbased WtE technologies, taking into account the importance of geographic conditions in two regions: Europe and Asia. Three WtE systems including one gasification plant and two incineration cases are considered, all of which are associated with differing specific operational data. The results are discussed with key parameters such as the choice of MSW composition, basis of displaced electricity, energy recovery mode, and application of "best-available technology" to incineration, aiming at exploring potential improvements for future developing WtE technology. The novelties of this paper attain at:

- Give a comprehensive comparison of incineration- and gasification-based WtE technologies. Such study could enrich the WtE inventory in LCA field. Besides, instead of using simulation, lab- or pilot-scale data which may raise uncertainties, industrial data are adopted, if available, average data at a national level. This could contribute to a transparency and consistent LCA result.

- Take into account the geographic aspects. This allows the comparison among regional waste systems to fulfil the design of local waste management systems.

\section{Methodology}

The LCA is carried out in agreement with the ISO standards (ISO, 2006) with four consecutive phases: (1) goal and scope definition; (2) life cycle inventory (LCI); (3) life cycle impact assessment (LCIA); and (4) interpretation. An "attributional" LCA approach is taken, which looks at "the environmentally relevant physical flows to and from a life cycle and its subsystems" (Finnveden et al., 2009). This selection is proven adequate when the aim is to compare the potential environmental impacts stemming from different processes or technologies (Arena et al., 2015a). 


\subsection{System boundaries, functional unit}

Fig. 1 provides an overview of the system boundaries and the most important flows. Three WtE systems are considered. S1 is the gasification case, of which MSW is firstly gasified followed by fully combustion for energy recovery. This type of plant configuration is adopted by most commercial pyrolysis/gasification-based WtE technologies currently available, and thus, the availability of data (Arena, 2012). The annually average operational data of a commercial Finnish plant, Kymijärvi II power plant, is selected for evaluation. S2 and S3 represent MSW incineration in France and China, respectively. The different waste composition and operating features based on a national level are addressed to reflect geographic aspects.

The functional unit is set at one ton of MSW. The system boundaries start at the gate of each WtE plant, stop at the moment when MSW becomes inert material, or useful energy, or environmental emissions. Hence, this LCA includes processes of MSW pretreatment, gasification/incineration conversion, energy recovery, flue gas cleaning, and solid residues disposal. MSW pre-treatment mainly refers to an upgrading process of pre-sorting, shredding and/or palletisation, for example SRF preparation in S1, or size reduction of the raw MSW in S3. Wastewater emission is not considered due to data scarcity; however, this assumption would not cause large deviation since state-of-the-art WtE is commonly designed with on-site wastewater reuse and recycling devices to meet a "zero discharge" target (Chen and Christensen, 2010).

Upstream activities, mainly the production of auxiliary materials and energy, are considered using data mainly from the Gabi database. The examined WtE systems allow for the recovery of energy as electricity and/or heat. The "multi-functional" processes are addressed by the use of system expansion: a same quantity of "avoided" emissions are subtracted from the system, which equal to the emissions that would be emitted, if energy was not recovered by WtE (Kourkoumpas et al., 2015). In appliance with the attributional LCA approach, a mix or average of energy sources in a specified region are used. Two sets of displaced electricity are selected, namely average European electricity mix, and that of the three specific countries' national grid mix. The former is used in the baseline cases; the latter will be discussed in the sensitivity analysis.

\subsection{Process model of waste-to-energy technologies}

S1: Gasification plant

The selected plant is the world's first gasification plant which uses SRF without adding auxiliary fuels (Lahti Energia). The plant is

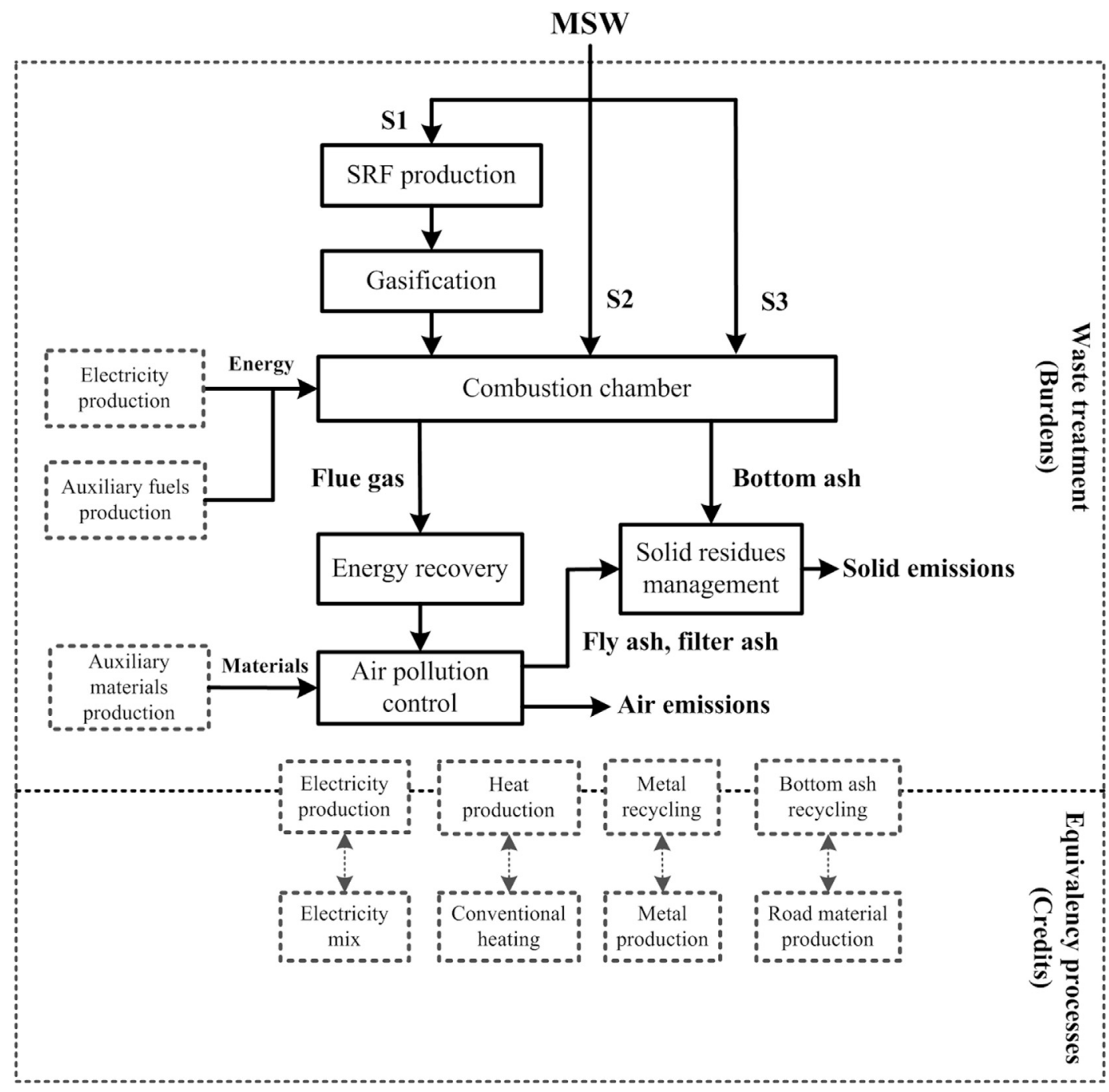

Fig. 1. System boundaries used in LCA depicting waste treatment and equivalency processes. SRF: solid recovered fuels. 
based on circulating fluidized bed (CFB) for the production of electricity (50 MW) and district heat (90 MW). Its commercial operation was started in 2012, and approximately 250,000 tons of SRF can be handled annually (Savelainen and Isaksson, 2015).

The gasifier runs at $850-900{ }^{\circ} \mathrm{C}$ under atmospheric pressure. As a result of gasification, the fuel, SRF, turns into syngas. The produced syngas then undergoes a cooling and purification step at $400{ }^{\circ} \mathrm{C}$. This temperature is chosen because on one hand, corrosioncaused impurities (e.g. alkali chlorides) can condense as solid particles; on the other hand, avoid tar condensation. Heat from the gas cooling step is recovered to preheat the feedwater. The cleaned syngas passes through a filter to remove particles, before combustion in a secondary chamber at $850^{\circ} \mathrm{C}$. The flue gas is relatively clean to bear a higher quality of steam superheated in the boiler $\left(540^{\circ} \mathrm{C}, 121 \mathrm{bar}\right)$, followed by final pollution control equipment to satisfy the regulated environmental standard (The Commission of the European Communities, 2007). For solid residues disposal, the produced bottom ash is landfilled; while the fly ash and air pollution control (APC) residues require safety stabilization before final disposal.

- S2: Mechanical-grate incineration in France

S2 represents MSW incineration in France. Data used for calculation are mainly from Beylot and Villeneuve (2013); Beylot et al. (2016) and Nzihou et al. (2012). The data represent 110 French incinerators ( $85 \%$ of the total number) currently in operation, thus could reflect the average emissions and energy consumptions of incinerators in France at a national level.

Incinerators in France are predominately MG type. A main advantage of MG incinerator is its capacity to treat unsorted waste. Raw waste is appropriately pushed over the grate, experiencing consecutively drying, devolatilization, and combustion along the moving grate. The excess air typically ranges from 1.6 to 2.2 to ensure complete combustion (Leckner, 2015). The energy is recovered into electricity and/or heat. In France, 37\% of the investigated plants are operated for electricity production; the average net efficiency attains at $14 \%$. In comparison, $26 \%$ and $37 \%$ is operated under co-generation of heat and power ( $\mathrm{CHP}$ ) and heat production only, respectively; with a respective efficiency of $33 \%$ and $43 \%$. Energy requirement of the plants is assumed to be supplied internally. Flue gas cleaning devices are equipped for dust, acid gases, $\mathrm{NO}_{\mathrm{x}}$ and $\mathrm{PCDD} / \mathrm{Fs}$ abatement; as a result, all the plants can meet the regulated emission limitation (The Commission of the European Communities, 2007).

\section{S3: Circulating fluidized bed incineration in China}

S3 reflects MSW incineration based on Chinese condition. The evaluation is based on CFB incineration due to its high capacity percentage in China; and thus, to represent a specific feature. The data source is mainly from Hong et al. (2017), who conducted both on-site and statistical study of typical incineration plants to obtain the country's representative operation data. The flowchart of a CFB plant experiences great similarities as that of MG; however, the incoming MSW should undergo size reduction before fed into the furnace. One of the most obvious advantages of CFB is the intense contact between the feedstock and bed material. As a consequence, excess air ratio could be reduced to around 1.4-1.5. The emissions at stack meet the national regulation (China State Environmental Protection Administration, 2014) attributed to the effectiveness of flue gas cleaning system. Energy from the waste is recovered to produce electricity. Average internal electricity consumption rate and recovery reaches $15 \%$ and $372 \mathrm{kWh}$, respectively (Hong et al., 2017).

\subsection{MSW composition}

Table 1 shows the MSW composition in each country based on national statistics, together with the European average as a reference (Beylot and Villeneuve, 2013; Christensen et al., 2009; Havukainen et al., 2016; Zhou et al., 2014). Raw MSW is handled in incineration plants, thus the French and Chinese national data in Table 1 are adopted as the input MSW composition in S2 and S3 system, respectively.

The considered gasification plant (S1) uses SRF as feedstock, which indicates, the input waste composition no more accords with the Finnish average in Table 1 as a result of refining process. The quality of the used SRF agrees with the European standard CEN/TC 343 , with its characteristics summarized in Table 2. The data represent an average of monthly measurement values (Savelainen and Isaksson, 2015), showing a much higher caloric value and a lower moisture content over the related raw MSW. Besides, the comparison of different systems based on an identical input MSW will be further discussed in the sensitivity analysis.

\subsection{MSW pre-treatment}

SRF production as an approach of raw waste upgrading is considered in S1. The waste is assumed to undergo size reduction, moisture reduction, followed by palletisation as SRF. According to the study of Nasrullah et al. (2015), the relevant energy consumption is assumed to be $70 \mathrm{kWh}$ of electricity per ton of MSW. $72 \%$ of the MSW ends up as SRF, and approximately $86 \%$ of the energy content of the waste is transferred to the SRF.

Homogenization of the incoming MSW is performed in S3 system. No accurate amount of the required electricity can be estimated; contrarily, this part of energy has been included as the plant

Table 1

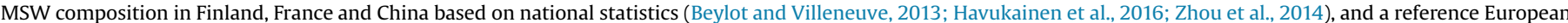
average based on Christensen et al. (2009).

\begin{tabular}{|c|c|c|c|c|c|c|c|c|}
\hline & \multicolumn{8}{|c|}{ Composition (wt.\%) } \\
\hline & Organic & Paper & Plastic & Wood & Textile & Glass & Metal & Other $^{\text {a }}$ \\
\hline Finland & 35.0 & 18.0 & 17.0 & 2.0 & 8.0 & 3.0 & 3.0 & 14.0 \\
\hline France & 39.6 & 16.2 & 11.7 & $2.6^{\mathrm{b}}$ & 2.3 & 6.3 & 3.0 & 18.3 \\
\hline China & 55.9 & 8.5 & 12.0 & 2.9 & 3.2 & n.m. ${ }^{c}$ & n.m. & $18.4^{\mathrm{d}}$ \\
\hline European average & 35.0 & 22.0 & 10.0 & n.m. & 3.0 & 6.0 & 4.0 & 20.0 \\
\hline
\end{tabular}

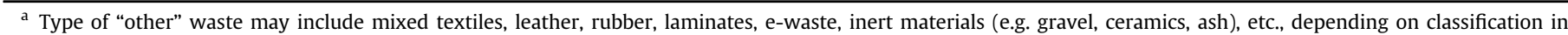
different countries.

b "Wood" in France may include other combustibles that not elsewhere classified.

c n.m.: not mentioned.

d "Other" waste in China refers to "non-combustibles" including glass and metal. 
Table 2

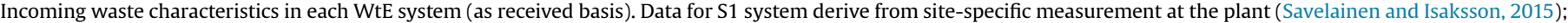
data for S2 and S3 systems are based on national statistics (Beylot and Villeneuve, 2013; Zhou et al., 2014).

\begin{tabular}{|c|c|c|c|c|c|}
\hline & Feedstock & LHV (MJ/kg) & Moisture (\%) & Ash (\%) & Carbon (\%) \\
\hline Gasification in Finland (S1) & SRF & 14.2 & 26.8 & 6.9 & 36.8 \\
\hline Incineration in France (S2) & MSW & 9.3 & 36.7 & 17.1 & 24.2 \\
\hline Incineration in China (S3) & MSW & 5.3 & 48.1 & 22.6 & 15.8 \\
\hline
\end{tabular}

LHV: lower heating value.

Table 3

Electricity mix based on European average, Finland, France and China (Unit: \%) (U.S. Energy Information Administration (EIA), 2012).

\begin{tabular}{|c|c|c|c|c|c|c|c|c|}
\hline & Fossil fuels & Nuclear & Hydroelectric & Geothermal & Solar & Tide and wave & Wind & Biomass and waste \\
\hline European average & 47.2 & 24.1 & 16.6 & 0.3 & 2.0 & 0.0 & 5.9 & 4.1 \\
\hline Finland & 25.5 & 32.7 & 24.7 & 0.0 & 0.0 & 0.0 & 0.7 & 16.4 \\
\hline France & 8.4 & 76.4 & 10.9 & 0.0 & 0.8 & 0.1 & 2.8 & 1.0 \\
\hline China & 77.1 & 1.9 & 18.0 & 0.0 & 0.1 & 0.0 & 2.0 & 0.9 \\
\hline
\end{tabular}

self-consumption.

\subsection{Energy recovery}

There are three modes for the recovery of energy: electricity, heat, or CHP. While all these options are available in France (S2), the investigated incineration plants in China (S3) are designed for electricity production only and the Finnish gasification plant (S1) is actually operated under CHP. Whereas the generated electricity can be delivered to the power grid relatively dependent of the location of the WtE plant, the utilization of the recovered heat requires the plant to be located adjacent to the demand for heat (Boesch et al., 2014). In order to minimize such geographic influence for a fair comparison, the baseline cases consider the production of electricity only, while the use of CHP is discussed as sensitivity analysis.

This study considers two types of electricity mix: European average (baseline cases), and the national grid mix of each specific country (sensitivity analysis). Table 3 presents the relevant distribution of the electricity grid (U.S. Energy Information Administration (EIA), 2012). As can be seen, fossil fuels are mostly consumed in China, nuclear energy dominates the French electricity mix, whilst the two types of electricity mix are balanced in Finland.

\subsection{Solid residues management}

The produced solid resides include bottom ash, fly ash and APC residues. They are assumed to be landfilled in the baseline cases, after a proper stabilization of the fly ash and APC residues. The quantities of the ashes as well as their leaching data are obtained based on on-site operation or related studies of each system (Autret et al., 2007; Dabo et al., 2009; Hong et al., 2017; Mengibar Guerrero, 2017; Savelainen and Isaksson, 2015). Sensitivity analysis further investigates the possibility of metal and ash recycling from S2, as it is the actual situation in France that $77 \%$ of the bottom ash is recycled in road works and $7 \%$ achieves metal recovery (Autret et al., 2007). The recycled materials are assumed to substitute the processes of road construction material production and primary ferrous metals production, respectively.

\subsection{Life cycle inventory}

An energy and material inventory is compiled by summarizing the total of processes data (Table 4). Biogenic $\mathrm{CO}_{2}$ is set as carbon neural and excluded from global warming. The fraction of biogenic carbon in S2 and S3 is calculated based on MSW composition (76\% and $74 \%$, respectively), while that value in S1 is estimated at $61 \%$ based on a typical SRF in Europe with average material composition of $30 \%$ paper and cardboard, 30\% wood, $37 \%$ plastic and 3\% textiles (Fruergaard and Astrup, 2011).

\subsection{Life cycle impact assessment}

The Danish EDIP 2003, a widely recognized LCIA methodology that developed in-line with the ISO standards, is chosen to aggregate the LCI results. Concerned environmental categories include both non-toxic and toxic impacts. However, in the following analysis in this study, toxic impacts via water are omitted as the impacts

Table 4

Life cycle inventory table for investigated systems (Functional unit: $1 \mathrm{t} \mathrm{MSW}$ ).

\begin{tabular}{|c|c|c|c|c|}
\hline & Unit & S1 & S2 & S3 \\
\hline \multicolumn{5}{|l|}{ Input streams } \\
\hline Electricity for SRF production & $\mathrm{kWh}$ & 70.0 & & \\
\hline Coal as auxiliary fuel & $\mathrm{kg}$ & & & 49.4 \\
\hline Fuel oil as auxiliary fuel & $\mathrm{L}$ & & 5.2 & \\
\hline Electricity for ash treatment & $\mathrm{kWh}$ & 2.1 & 1.3 & 2.4 \\
\hline Diesel for ash treatment & $\mathrm{L}$ & 2.4 & 5.6 & 2.3 \\
\hline Lime for flue gas purification & $\mathrm{kg}$ & & 10.2 & 9.6 \\
\hline Sodium hydroxide for flue gas purification & $\mathrm{kg}$ & & 2.0 & \\
\hline Sodium bicarbonate for flue gas purification & $\mathrm{kg}$ & 12.1 & & \\
\hline Activated carbon for flue gas purification & $\mathrm{kg}$ & 0.6 & 1.0 & 0.5 \\
\hline Urea for flue gas purification & $\mathrm{kg}$ & 0.6 & 2.9 & \\
\hline \multicolumn{5}{|l|}{ Output streams } \\
\hline Net electricity output ${ }^{a}$ & $\mathrm{kWh}$ & 777.2 & 361.0 & 317.0 \\
\hline Bottom ash & $\mathrm{kg}$ & 50.2 & 238.0 & 40.9 \\
\hline Fly ash and air pollution control residues & $\mathrm{kg}$ & 58.4 & 34.3 & 65.8 \\
\hline \multicolumn{5}{|l|}{ Direct air emissions } \\
\hline $\mathrm{CO}$ & $\mathrm{g} / \mathrm{t}$ & 8.1 & 51.0 & 952.1 \\
\hline $\mathrm{SO}_{2}$ & $\mathrm{~g} / \mathrm{t}$ & 28.2 & 51.2 & 492.3 \\
\hline $\mathrm{NO}_{\mathrm{x}}$ & $\mathrm{g} / \mathrm{t}$ & 649.7 & 927.0 & 1060.0 \\
\hline $\mathrm{HCl}$ & $\mathrm{g} / \mathrm{t}$ & 4.0 & 18.3 & 48.5 \\
\hline $\mathrm{HF}$ & $\mathrm{g} / \mathrm{t}$ & 2.0 & 0.9 & 2.6 \\
\hline Particulate matters (PM) & $\mathrm{g} / \mathrm{t}$ & 8.1 & 8.7 & 48.6 \\
\hline PCDD/Fs & $\mathrm{g} / \mathrm{t}$ & $8.1 \mathrm{E}-9$ & $7.0 \mathrm{E}-8$ & $3.2 \mathrm{E}-7$ \\
\hline \multicolumn{5}{|l|}{ Direct solid emissions } \\
\hline Cadmium & $\mathrm{mg} / \mathrm{t}$ & 0.2 & 71.4 & 14.7 \\
\hline Chromium & $\mathrm{mg} / \mathrm{t}$ & 1.6 & 95.3 & 29.6 \\
\hline Copper & $\mathrm{mg} / \mathrm{t}$ & 311.2 & 5497.8 & $1.3 \mathrm{E}-3$ \\
\hline Lead & $\mathrm{mg} / \mathrm{t}$ & 65.2 & 1975.4 & 68.7 \\
\hline Nickel & $\mathrm{mg} / \mathrm{t}$ & 1.0 & 547.4 & 160.3 \\
\hline Zinc & $\mathrm{mg} / \mathrm{t}$ & 125.5 & 5497.8 & 2190.0 \\
\hline
\end{tabular}

${ }^{a}$ As net electricity output, i.e., the internal electricity consumption inside the plant has been deducted from the gross electricity generation.

b Wastewater generated during MSW treatment is not considered due to the lack of data. 
Table 5

Impact categories, characterization unit and normalization references based on EDIP 2003 methodology.

\begin{tabular}{lll}
\hline Impact category & $\begin{array}{l}\text { Characterization } \\
\text { unit }\end{array}$ & $\begin{array}{l}\text { Normalization } \\
\text { references }\end{array}$ \\
\hline $\begin{array}{l}\text { Global warming (GW) } \\
\text { Acidification (AC) }\end{array}$ & $\begin{array}{l}\mathrm{kg} \mathrm{CO}_{2} \text {-equivalent } \\
\mathrm{m}^{2} \text { unprotected } \\
\text { ecosystem }\end{array}$ & $\begin{array}{l}8700 \\
2200\end{array}$ \\
$\begin{array}{l}\text { Terrestrial eutrophication (TE) } \\
\mathrm{m}^{2} \text { unprotected } \\
\text { ecosystem }\end{array}$ & 2100 \\
$\begin{array}{l}\text { Photochemical ozone formation } \\
\text { to human health (POFh) }\end{array}$ & persm·hour & 10 \\
$\begin{array}{l}\text { Human toxicity via air (HTa) } \\
\text { Human toxicity via solid (HTs) }\end{array}$ & $\begin{array}{l}\mathrm{m}^{3} \text { air } \\
\mathrm{m}^{3} \mathrm{solid}\end{array}$ & $2,090,000,000$ \\
Ecotoxicity via solid (ETs) & $\mathrm{m}^{3}$ solid & 157 \\
\hline
\end{tabular}

are insignificant compared with the other toxicity categories. Consequently, seven impacts will be further analysed, namely global warming $(\mathrm{GW})$, acidification $(\mathrm{AC})$, terrestrial eutrophication (TE), photochemical ozone formation to human health (POFh), human toxicity via air (HTa) and solid (HTs), and ecotoxicity via solid (ETs). Results based on normalized values are used to examine the relative magnitude of each impact into person equivalence (PE). The scale for GW is global; while that for all other impacts is based on Europe. Information on the characterization and normalization references is indicated in Table 5.

\section{Results}

Comparing the normalized environmental impacts of different WtE systems (Fig. 2), results reveal that gasification scenario (S1) exhibits the lowest potential effect on each category. The impacts of S1 are generally appeared as negative values (except for ETs with a relatively low value), which actually indicate net environmental savings. By contrast, MSW incineration under the condition of
China (S3) exhibits the highest impacts for most categories (GW, AC, TE, POFh and HTa), while incineration in France (S2) is the most inferior to toxic-related categories of HTs and ETs. With respect to the dominant impacts to LCA, Fig. 2 also elucidates that HTs from S2 and $\mathrm{S} 3$ is the most significant contribution to the overall impact. AC is another principle factor affected by S1, however it is presented as an environmental benefit.

To identify the key processes and substances, the total environmental impacts are divided into several processes: energy/ materials provision, stack emissions, energy recovery, and residues management (Fig. 3). Results show that a large fraction of the environmental loadings is offset by energy recovery, avoiding a great amount of pollutants produced based on fossil fuels. S1 leads to this highest environmental saving due to its substantial increase in the amount of energy recovered. The benefits should be attributed to the use of gasification-incineration scheme, which allows cleaning of the produced gas before fully oxidation. The cleaned gas allows the boiler to employ higher steam data than that used in a conventional waste boiler $\left(540^{\circ} \mathrm{C}, 121 \mathrm{bar}\right.$ in comparison to $400^{\circ} \mathrm{C}$, 40 bar in MSW incineration plant (Arena et al., 2015a)), thus the electricity generation efficiency is improved effectively (net efficiency of $27 \%$ ).

Among the environmental loading processes, stack emissions are the main contributor. S1 is again effective for their reduction (except for GW) compared with incineration cases of S2 and S3. To further indicate the key substances, a proportional analysis of each pollutant is conducted (Fig. 4). $\mathrm{NO}_{\mathrm{x}}$ is found to be a principal contributor to the total stack emissions. Its proportion in $\mathrm{S} 1$ shows a positive reduction compared with S2 owing to an effective control, for instance, homogeneous gas-gas reaction in the combustor. S3 exhibits a lowest proportion of $\mathrm{NO}_{\mathrm{x}}$ regarding $\mathrm{AC}$, which however should be attributed to the high amount of $\mathrm{SO}_{2}$ generated, being $12-$ times greater than that in S1. A dramatic reduction of $\mathrm{HCl}$ in $\mathrm{S} 1$ is also observed. However, Fig. 3 shows that the stack GW emissions from $\mathrm{S} 1$ is the highest, while $\mathrm{CO}_{2}$ is found to be the most crucial

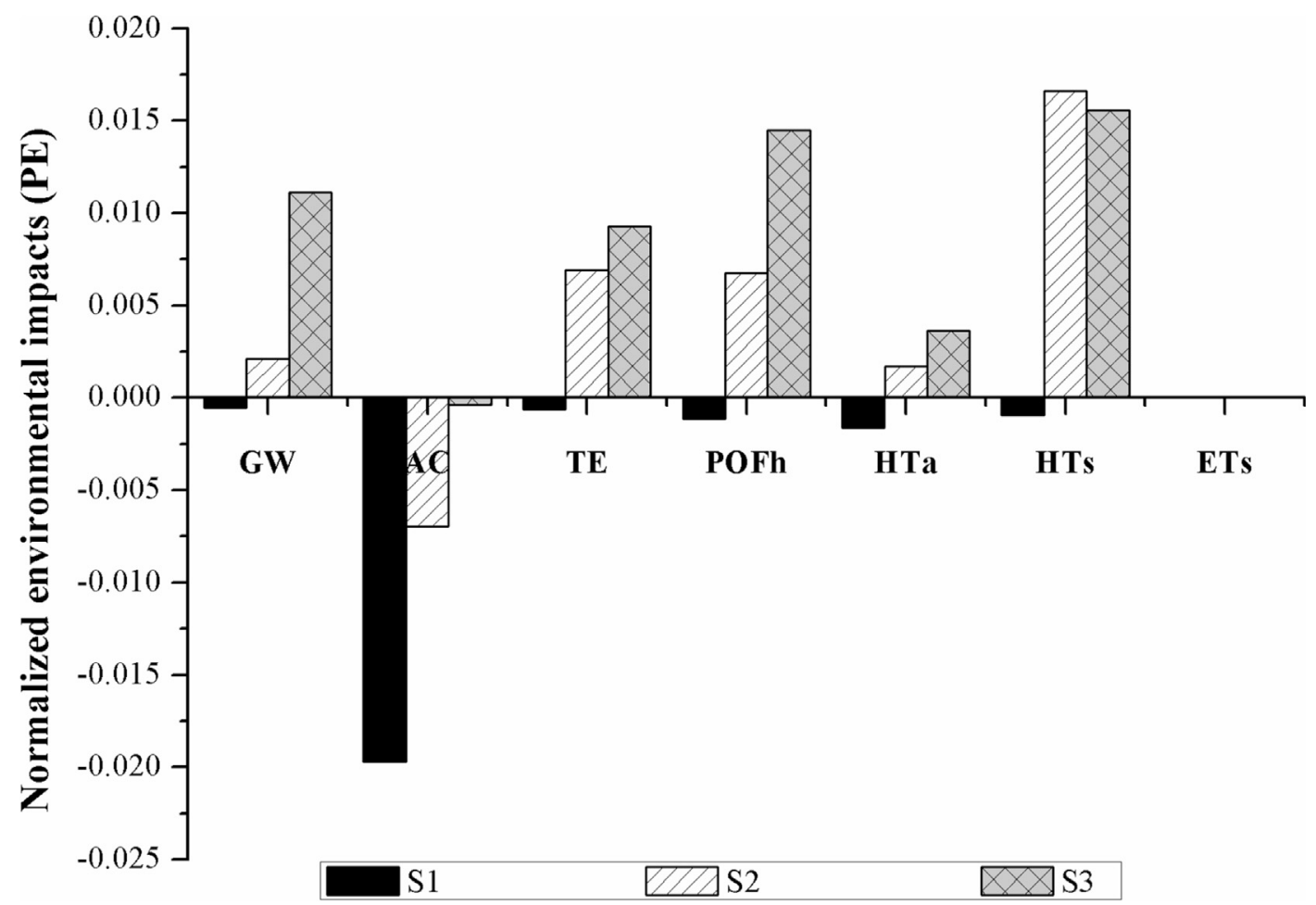

Fig. 2. Normalized environmental impacts: S1, gasification plant in Finland; S2, mechanical-grate incineration in France; S3, fluidized bed incineration in China. 


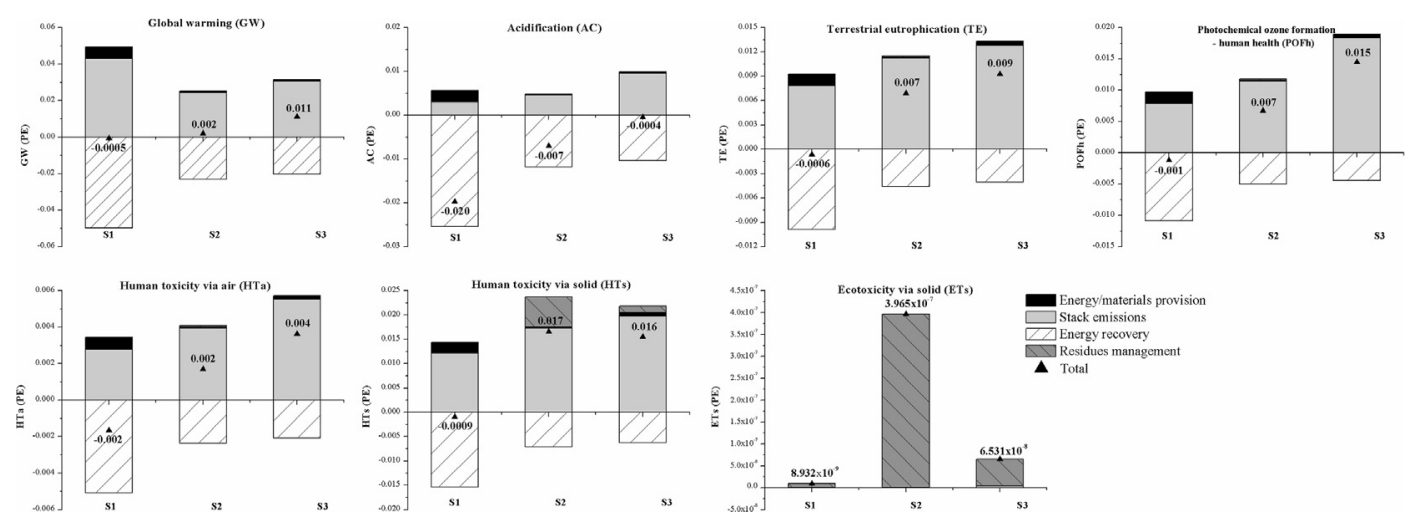

Fig. 3. Contribution analysis of each impact category: S1, gasification plant in Finland; S2, mechanical-grate incineration in France; S3, fluidized bed incineration in China.

contributor from Fig. 4. $\mathrm{CO}_{2}$ in the flue gas is a result of waste composition and is not addressed by flue gas cleaning system (Astrup et al., 2009). The higher stack GW impact of S1 is thus a result of the higher share of non-biogenic carbon in the waste (Table 2). However, this GW loading in S1 is effectively counterbalanced by the benefit from a higher amount of electricity recovered; thus leading to its lowest overall GW impact.

Residues management is the main process contributor to soilbased toxic impacts, i.e., HTs and ETs; to be more specific, the leaching of heavy metals after landfill. Their effects are more obvious in S2, which is mainly due to the large quantity of bottom ashes generated from MB incineration.

Overall, the environmental improvement of the gasification- based WtE system (S1) verifies a significant role of the syngas purification, which can not only reduce the emissions at stack, but also allow a higher steam parameter to increase the overall energy efficiency.

A parallel comparison between the two incineration cases is also conducted. It appears that plants under the condition of China (S3) lead to an inferior performance than France (S2). The reasons are partly due to the low quality of the incoming waste. As seen from Table 2, MSW in China is characterized with more organic fraction that the caloric value is relatively low. This has resulted in a decreased amount of the energy recovered compared with S2, although the energy efficiency of CFB incinerators is actually even higher than $\mathrm{MB}$ incinerators (21\% vs. $14 \%$ in this study).
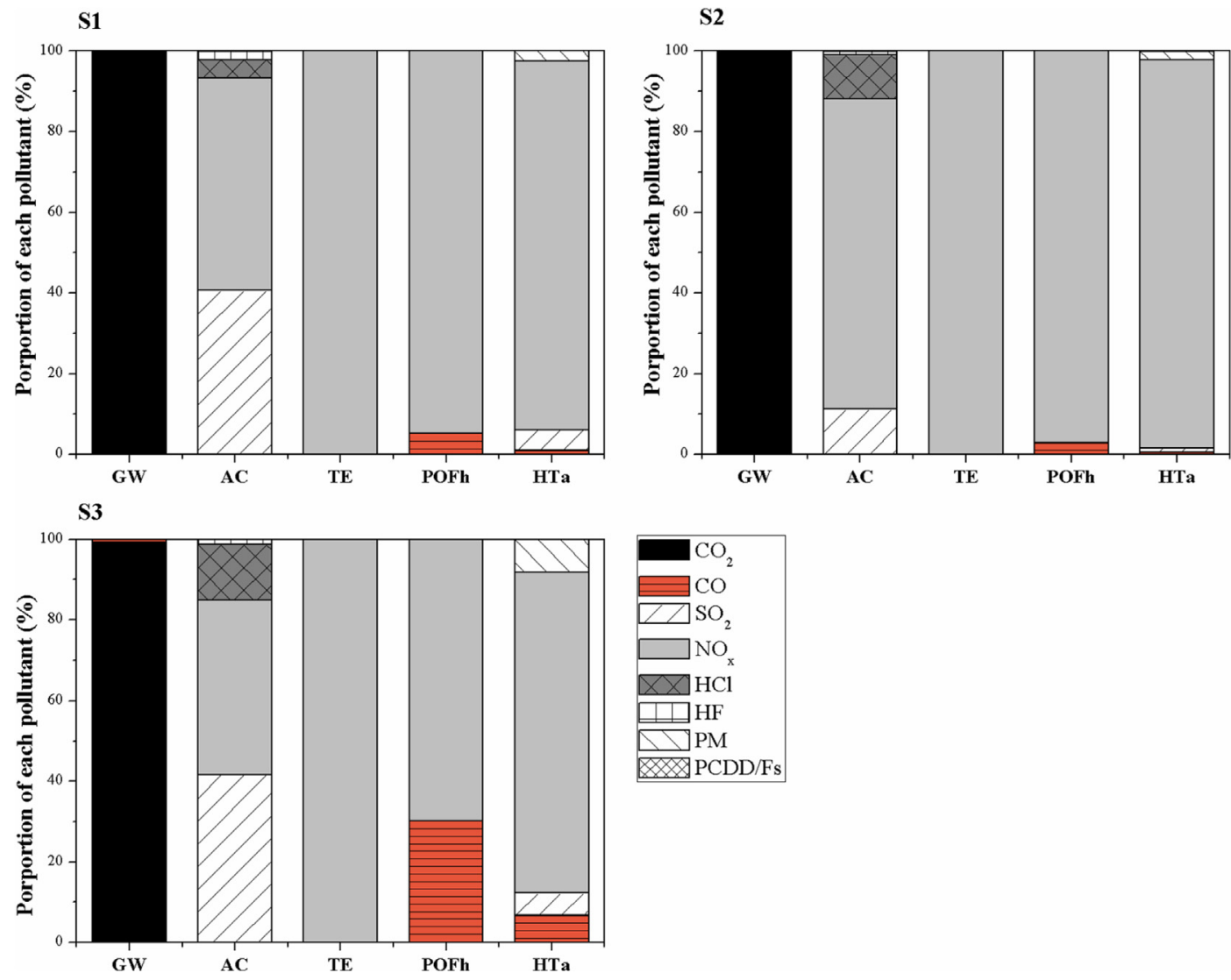

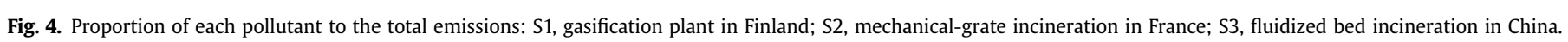


Table 6

Comparison of Chinese and European standards for MSW incineration pollution control (durations of 24-h average) (China State Environmental Protection Administration, 2014; The Commission of the European Communities, 2007).

\begin{tabular}{llll}
\hline $\begin{array}{l}\text { Air } \\
\text { emissions }\end{array}$ & Unit & $\begin{array}{l}\text { China National Standard, } \\
\text { GB18485-2014 }\end{array}$ & $\begin{array}{l}\text { European Community } \\
\text { Guidelines, 2007/76/EC }\end{array}$ \\
\hline $\mathrm{CO}$ & $\mathrm{mg} / \mathrm{m}^{3}$ & 80 & 50 \\
$\mathrm{SO}_{2}$ & $\mathrm{mg} / \mathrm{m}^{3}$ & 80 & 50 \\
$\mathrm{NO}_{\mathrm{x}}$ & $\mathrm{mg} / \mathrm{m}^{3}$ & 250 & 200 \\
$\mathrm{HCl}$ & $\mathrm{mg} / \mathrm{m}^{3}$ & 50 & 10 \\
$\mathrm{HF}$ & $\mathrm{mg} / \mathrm{m}^{3}$ & $\mathrm{n} / \mathrm{a}$ & 1 \\
$\mathrm{PM}$ & $\mathrm{mg} / \mathrm{m}^{3}$ & 20 & 10 \\
$\mathrm{PCDD} / \mathrm{Fs}$ & $\mathrm{ng} \mathrm{TEQ} / \mathrm{m}^{3}$ & 0.1 (Test average) & $0.1(6-8$ h average $)$ \\
\hline
\end{tabular}

Additionally, an auxiliary coal is used in S3, which has increased the input energy consumption; at the same time, being an emission source especially fossil-derived $\mathrm{CO}_{2}$. With respect to the key pollutants, $\mathrm{SO}_{2}, \mathrm{CO}, \mathrm{HCl}$ and $\mathrm{PM}$ from $\mathrm{S} 3$ are more relevant than $\mathrm{S} 2$. These stack emissions have resulted in higher AC, TE, POFh and HTa loadings. Table 6 further compares the MSW incineration pollution control standards in China and Europe (China State Environmental Protection Administration, 2014; The Commission of the European Communities, 2007). The figures clearly indicate the necessity of a more stringent air pollution control limitation as an improvement. Besides, increasing the waste calorific value can be another feasible improvement, by enhancing the level of MSW source separation under the current waste management situation in China. In view of incinerators in France, HTs and ETs exhibit the worst performance. Proper residues management is the key aspect to control heavy metal leaching to the soil, and this will be further discussed in the sensitivity analysis.

\section{Sensitivity and uncertainty analysis}

To evaluate the robustness of the LCA results, the uncertainties are addressed in two parts: scenario and parameter uncertainties (Astrup et al., 2015). The former deals with the uncertainty due to intrinsic modelling assumptions. This is addressed by sensitivity analyses involving four variations: choice of MSW composition, basis of displaced electricity, energy recovery based on CHP, and application of "best-available technology" dedicated to incineration. The latter is performed by increasing each input parameter by $10 \%$ individually to evaluate the consequences for the environmental impacts.

\subsection{Comparison under an identical MSW composition}

The core objective of this study is to examine the relative environmental sustainability of three WtE alternatives with a focus on the influence of geographic conditions. However, the different plant locations may be a source of bias from the perspective of LCA. MSW composition varies among different regions, which could cause difficulty to attribute potential advantages/disadvantages to WtE technologies (gasification or incineration) or local waste systems (MG or CFB, emission regulations). The influence of this issue is evaluated through a sensitivity analysis, where the three WtE systems are compared under an identical MSW composition. The waste from France is now also used for Finnish gasification and Chinese incineration cases, namely, $\mathrm{S} 1_{\mathrm{MSW}-\mathrm{FR}}$ and $\mathrm{S} 3_{\mathrm{MSW}}$-FR. This assumption is accompanied by excluding SRF production step in $\mathrm{S} 1_{\mathrm{MSW}-\mathrm{FR}}$ and ancillary fuel (coal) addition in $\mathrm{S} 3_{\mathrm{MSW}-\mathrm{FR}}$, while the remaining operation parameters (plant efficiency, emission factors, etc.) are kept as before. The changes of the final environmental impacts are summarized in Table 7, with the mostly affected categories, GW, AC, POFh and HTs, discussed in Fig. 5.

It is notable that the ranking of the three systems does not

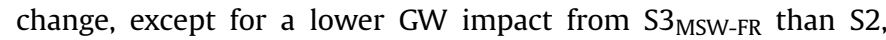
mainly due to a higher energy efficiency of the CFB incineration that results in greater savings from energy recovery. The gasification system ( $\left.\mathrm{S} 1_{\mathrm{MSW}-\mathrm{FR}}\right)$ is again the most preferable over incineration systems of S2 and S3 $3_{M S W-F R}$ in all impact categories. This environmental advantage should be completely attributed to the use of gasification-based WtE technology. As verified by the contribution analysis (Fig. 5), the improvement of $S 1_{M S W-F R}$ is linked with two aspects, decreased emissions at stack and a higher energy recovery efficiency. Meanwhile, $\mathrm{S}_{\mathrm{MSW}} \mathrm{FR}$ is still inferior to $\mathrm{S} 2$ regarding the majority of impacts including AC, NE, POF and HTa, despite the fact

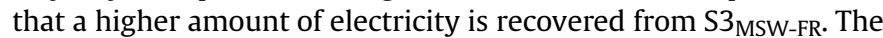
determining factor, as revealed by Fig. 5, is attributed to higher emission factors, and thus, a higher amount of emissions at stack. The observations verify the importance of a stricter emission standard in China, as previously discussed in Table 6.

The Finnish gasification plant in fact uses SRF as feedstock. The aim is to upgrade the fuel quality of raw MSW, since gasification necessarily requires more stringent feedstock properties to maintain steady operation (Shehzad et al., 2016). The effect of using SRF is also investigated by assuming a $\mathrm{S} 1_{\mathrm{MSW}}$-FR-SRF scenario, which represents SRF production from the French MSW in combination with gasification in the specified plant. Fig. 5 indicates that the SRF gasification case ( $\left.\mathrm{S} 1_{\mathrm{MSW}-\mathrm{FR}-\mathrm{SRF}}\right)$ generally exhibits increased

Table 7

Summary of the normalized environmental impacts of the baseline scenarios and each alternative in the sensitivity analysis (Unit: PE).

\begin{tabular}{|c|c|c|c|c|c|c|c|}
\hline System ${ }^{a}$ & GW & $A C$ & TE & POFh & HTa & HTs & ETs \\
\hline S1 & -0.0005 & -0.020 & -0.0006 & -0.001 & -0.002 & -0.0009 & $8.932 \times 10^{-9}$ \\
\hline S2 & 0.002 & -0.007 & 0.007 & 0.007 & 0.002 & 0.017 & $3.965 \times 10^{-7}$ \\
\hline S3 & 0.011 & -0.0004 & 0.009 & 0.015 & 0.004 & 0.016 & $6.531 \times 10^{-8}$ \\
\hline $\mathrm{S} 1_{\mathrm{MSW}-\mathrm{FR}}$ & -0.019 & -0.020 & -0.001 & -0.002 & -0.002 & -0.0003 & $1.155 \times 10^{-7}$ \\
\hline $\mathrm{S} 3_{\mathrm{MSW}-\mathrm{FR}}$ & -0.010 & -0.006 & 0.008 & 0.014 & 0.003 & 0.014 & $7.224 \times 10^{-8}$ \\
\hline $\mathrm{S} 1_{\mathrm{MSW}-\mathrm{FR}-\mathrm{SRF}}$ & -0.009 & -0.015 & -0.001 & -0.002 & -0.002 & -0.0008 & $8.313 \times 10^{-8}$ \\
\hline $\mathrm{S} 1_{\mathrm{ES}}$ & 0.005 & -0.004 & 0.002 & -0.0009 & 0.0001 & 0.003 & $8.648 \times 10^{-9}$ \\
\hline $\mathrm{S} 2 \mathrm{ES}$ & 0.019 & 0.003 & 0.010 & 0.010 & 0.004 & 0.022 & $3.966 \times 10^{-7}$ \\
\hline $\mathrm{S} 3_{\mathrm{ES}}$ & -0.007 & -0.027 & -0.004 & 0.0007 & -0.003 & -0.004 & $6.547 \times 10^{-8}$ \\
\hline $\mathrm{S} 1_{\mathrm{CHP}}$ & -0.071 & -0.050 & -0.019 & -0.022 & -0.011 & -0.030 & $8.537 \times 10^{-9}$ \\
\hline $\mathrm{S} 2_{\mathrm{CHP}}$ & -0.027 & -0.019 & -0.002 & -0.003 & -0.003 & 0.003 & $3.964 \times 10^{-7}$ \\
\hline $\mathrm{S} 2_{\mathrm{BAT}}$ & -0.020 & -0.018 & 0.001 & 0.0004 & -0.001 & 0.003 & $6.452 \times 10^{-8}$ \\
\hline
\end{tabular}

a Subscript letter "MSW-FR" stands for "using the French MSW composition" in specified systems; "MSW-FR-SRF" means "using solid refuse fuels made from French MSW

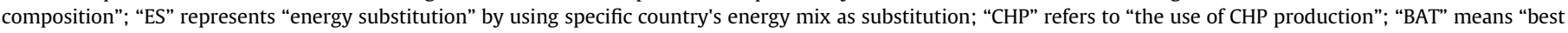
available technology" that is applied in the specified system. 

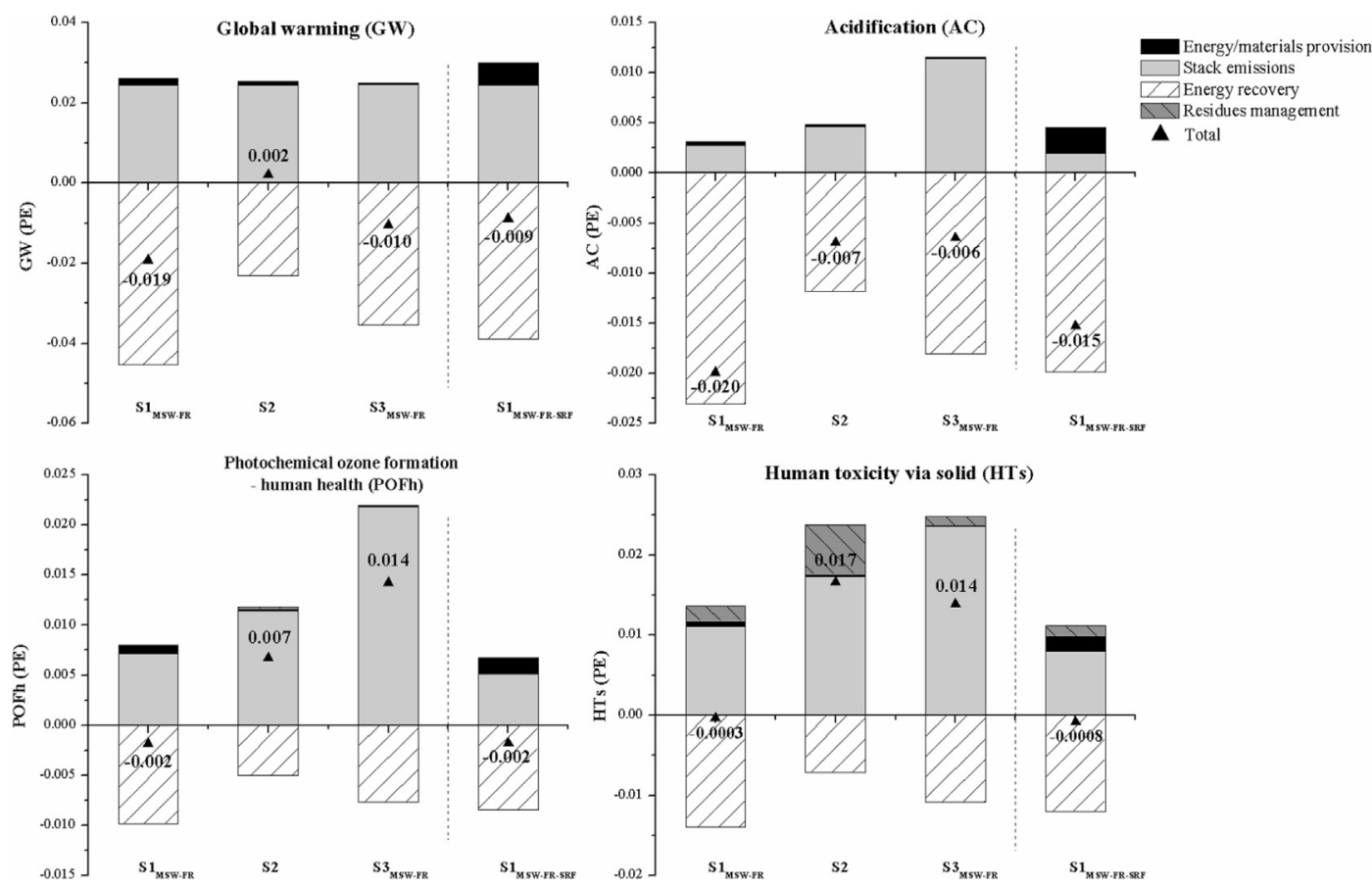

Fig. 5. Effect of using an identical MSW composition to selected impact categories: S1, gasification plant in Finland; S2, mechanical-grate incineration in France; S3, fluidized bed incineration in China; superscript letter "MSW-FR" stands for "using the French MSW composition" in specified systems; "MSW-FR-SRF" represents "using solid refuse fuels made from French MSW composition".

impacts than its gasification from raw MSW (S1 $\left.1_{\mathrm{MSW}-\mathrm{FR}}\right)$. The key attributor, as mentioned in Section 2.4, is that approximately $14 \%$ of the energy content of the MSW is lost during SRF production, leading to a decreased amount of electricity recovered. Compared with S1 $1_{\text {MSW-FR, }}$ S1 $1_{\text {MSW-FR-SRF }}$ only shows an insignificant improvement regarding HTs and ETs, due to a $28 \%$ mass loss in processing MSW to SRF that has decreased the amount of ash to be disposed. On the other hand, SRF gasification ( $\left.\mathrm{S} 1_{\mathrm{MSW}-\mathrm{FR}-\mathrm{SRF}}\right)$ is still much better than both incineration cases (S2, S3 3 MSW-FR). This reveals the fact that the use of gasification technology, owing to its

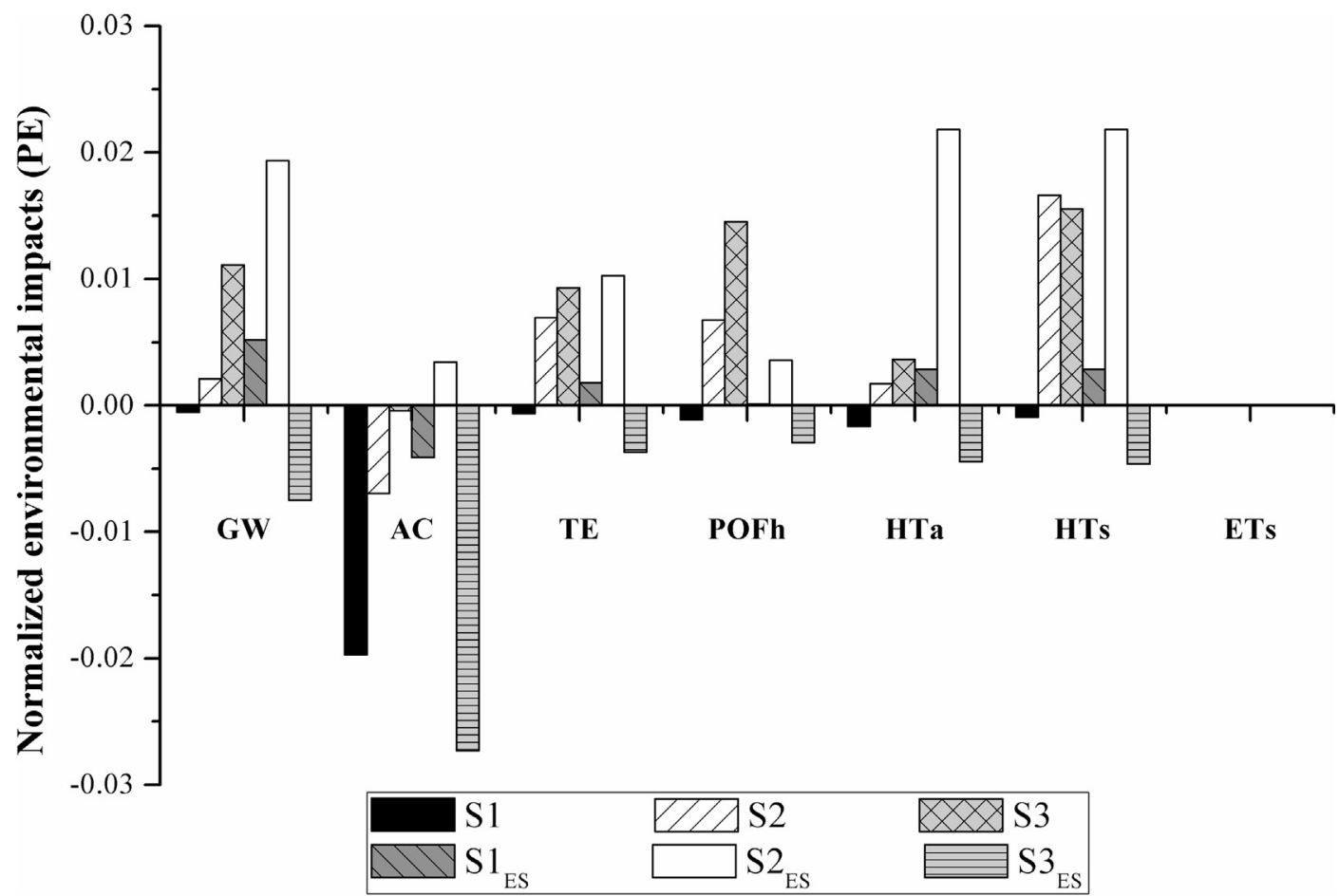

Fig. 6. Effect of energy structure to the normalized environmental impacts: S1, gasification plant in Finland; S2, mechanical-grate incineration in France; S3, fluidized bed incineration in China; subscript letter "ES" represents "energy structure" by using specific country's energy mix as substitution. 
advantages of a higher efficiency and lower emissions, could well counterbalance the energy loss and extra energy demand in processing raw MSW to produce SRF.

Overall, the comparison by using an identical MSW composition shows that gasification represents a promising WtE technology over incineration. Raw MSW gasification is theoretically an optimal option, however regarding practical operation, the use of SRF as raw MSW upgrading is necessary and SRF gasification could serve as an improvement of the current WtE.

\subsection{Choice of energy structure}

In baseline cases, the electricity produced is assumed to substitute that produced based on average European electricity mix. Since the energy structure of each specific country varies greatly, its influence is investigated. Table 7 and Fig. 6 reveal that the relevant environmental impacts of incineration in China ( $\left(\mathrm{S}_{\mathrm{ES}}\right)$ would experience a significant decrease if the country-specific energy structure data are used. Specifically, S3 $3_{\mathrm{ES}}$ can surpass gasification ( $\left.\mathrm{S} 1, \mathrm{~S} 1_{\mathrm{ES}}\right)$ and performs the best among different systems. This result is based on the fact that China is more dependent on non- renewable fuels that produce heavier pollutants. Conversely, $\mathrm{S} 1_{\mathrm{ES}}$ and $\mathrm{S} 2_{\mathrm{ES}}$ become less environmental-friendly in comparison to their baseline, attributed to a higher ratio of renewable energy applied (8\%, 25\% and 47\% fossil fuels in France, Finland and European average, respectively, see Table 3 ). The analysis indicates that assumptions on the displaced energy are crucial to the overall results. Comparison of different WtE technologies should carefully address the geographic factors to adequately account for the effects of energy recovery under regional conditions.

\subsection{Choice of combined heat and electricity production}

As aforementioned, the selected gasification plant (S1) is actually operated under CHP mode (additional 61\% heat efficiency (Savelainen and Isaksson, 2015)), while 26\% French incinerators (S2) are also equipped with CHP production (average 6\% electricity efficiency and 41\% heat efficiency (Beylot et al., 2016)). As a consequence, the use of CHP is also investigated, identified respectively as $\mathrm{S} 1_{\mathrm{CHP}}$ and $\mathrm{S} 2_{\mathrm{CHP}}$. The environmental impacts shown in Table 7 and Fig. 7 reveal relatively large environmental savings by the use of CHP mode, namely, the increased substitution of fossil
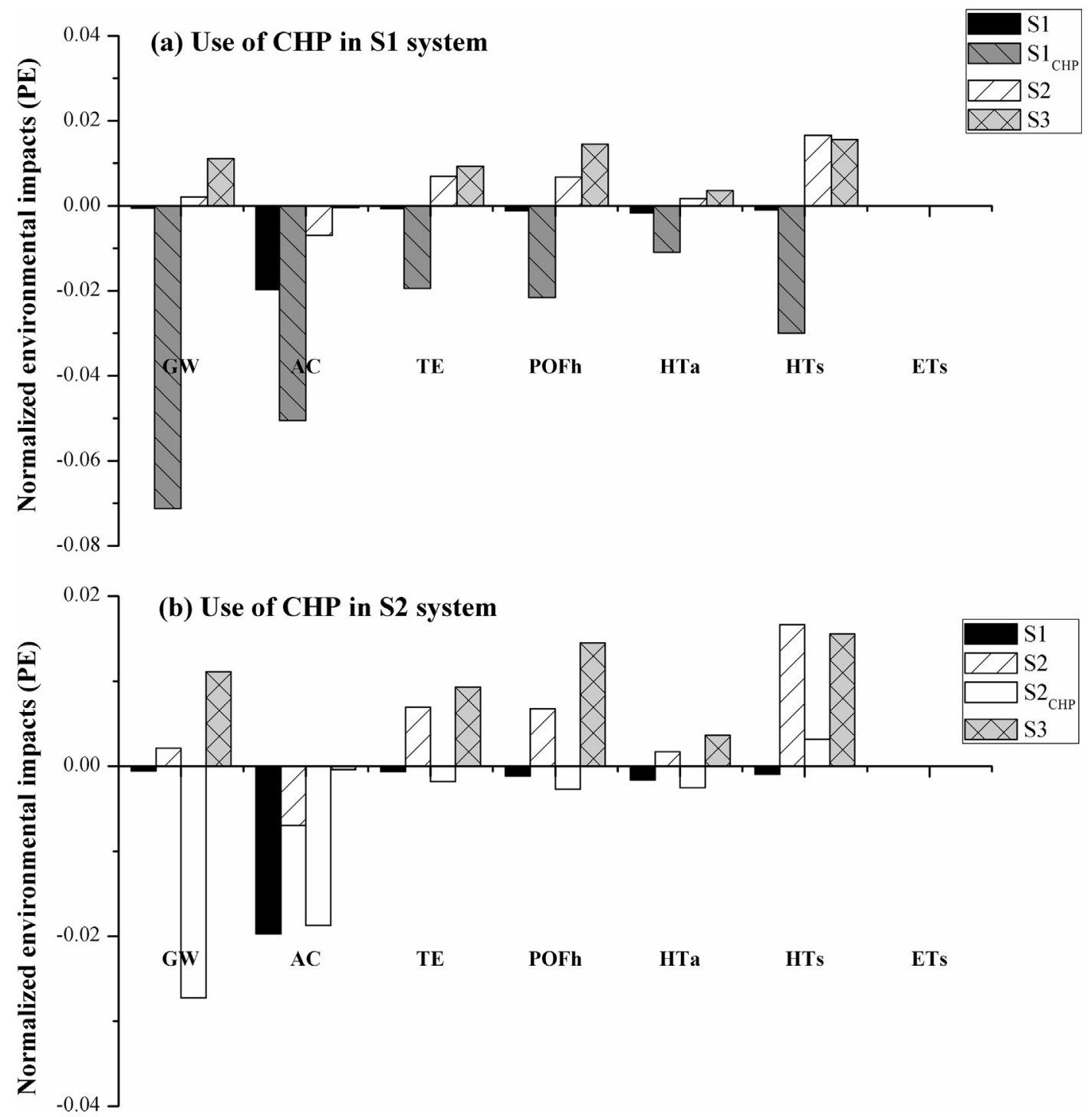

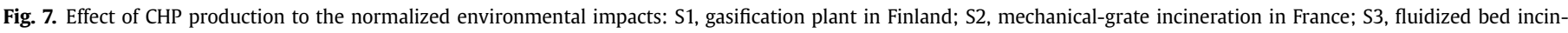
eration in China; superscript letter "CHP" represents the use of CHP production in specified system. 

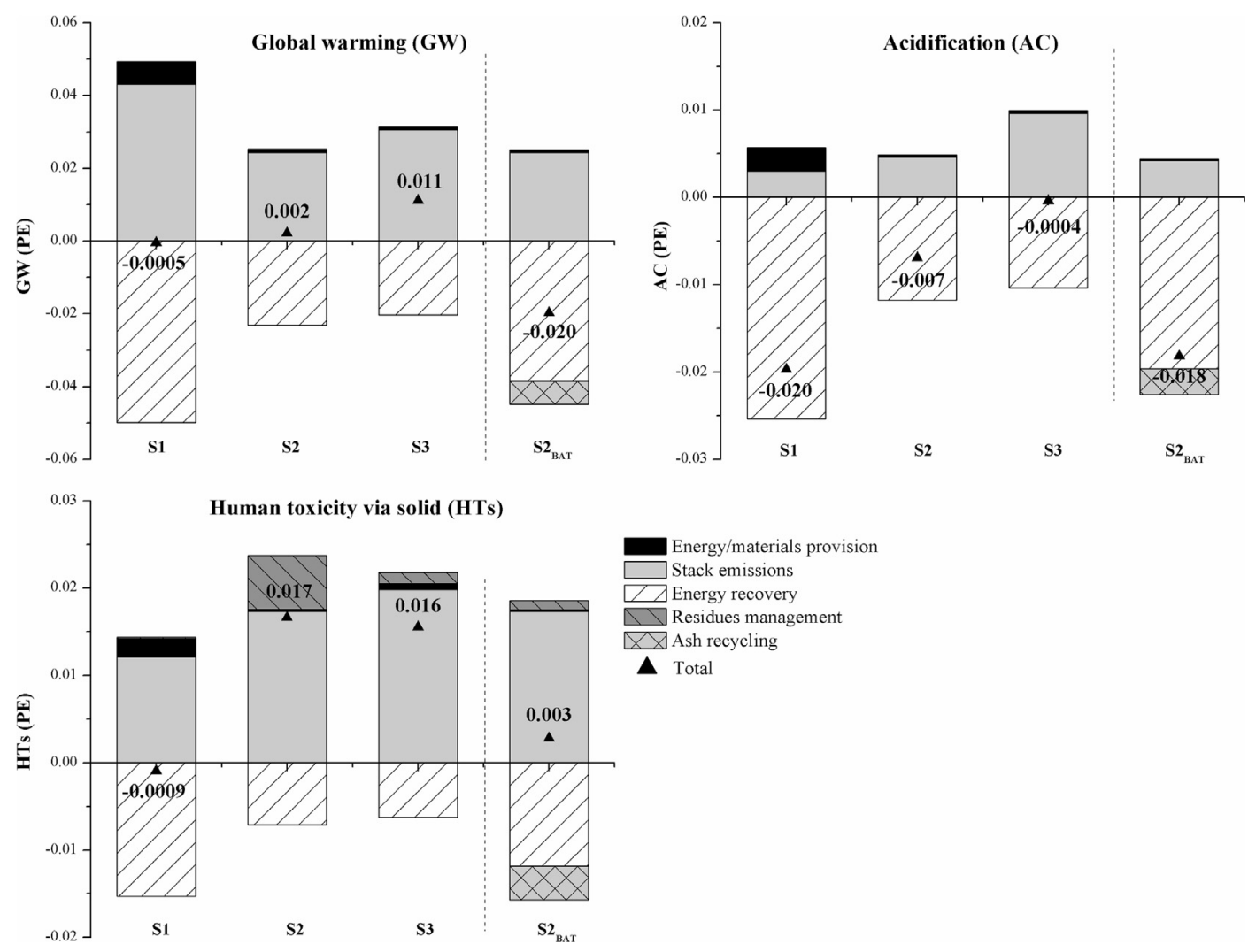

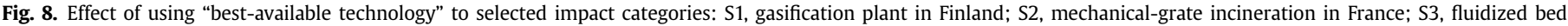
incineration in China; superscript letter "BAT" represents "best available technology" applied in specified system.

fuels used for energy production and their emissions. Specifically, $\mathrm{S} 2_{\mathrm{CHP}}$ has surpassed $\mathrm{S} 1$ and become the most environmentally sustainable option in respect to GW, TE, POFh and HTa impacts. The results demonstrate an important role of enlarging the overall energy efficiency. CHP is more thermally efficient use of fuel than electricity generation alone. However, the feasibility of its application should also consider the location of the WtE plant to have a constant demand for district heating (Burnley et al., 2015).

\subsection{Use of "best-available technology" in incineration plants}

The alternative also defines a "best-case" scenario to incineration, which is based on S2 with some improved data from the most up-to-date units of the incineration plants as reported by Arena et al. (2015a): (1) the net electricity recovered is increased to $600 \mathrm{kWh} / \mathrm{t}-\mathrm{MSW}$ that equals to a net efficiency of $23 \%$ based on French MSW; (2) an improved control of $\mathrm{HCl}$ and PCDD/Fs is assumed at $5 \mathrm{~g} / \mathrm{t}-\mathrm{MSW}$ and $20 \mathrm{ng} / \mathrm{t}-\mathrm{MSW}$, respectively; and (3) the bottom ash achieves recycling in road works (77\%) and metal recovery (7\%), which accords to the actual situation in France. The comparison of the obtained impacts is listed in Table 7, of which the most relevant categories (GW, AC and HTs) are analysed in Fig. 8. As expected, S2 $2_{\mathrm{BAT}}$ scenario exhibits a better performance than its baseline (S2), and, is superior to gasification (S1) in terms of GW. The contribution from different processes again confirms a dominant role of a more efficient energy recovery. Bottom ash recycling also shows two-aspects benefits responsible for the improved environment: the reduced amount of ash to be treated, which is the main cause of HTs by heavy metals leaching; and, the avoided manufacture of road construction material and metals from virgin materials.

\subsection{Parameter uncertainty analysis}

A $10 \%$ increment of each input parameter is implemented in the LCA modelling, the sensitivity ratio (SR), defined as the ratio between the relative change in a specific impact category and the relative change in a parameter, is calculated. A same trend of SR values is observed for all the three systems, with that for S2 system presented in Fig. 9. The results indicate, among the 30 input parameters (waste properties, electricity recovery, emission factors, solid residues, materials/energy provision, etc.), only 7 parameters have SR values greater than \pm 0.1 for $S 2$, i.e. corresponding to changes in final impact larger than $10 \%$ based on a $10 \%$ increment in input parameter. Some parameters have impacts across a number of impacts (e.g. $\mathrm{NO}_{\mathrm{x}}$ emission, amount of electricity recovered), while others are important only to certain impacts (e.g. $\mathrm{CO}_{2}$ emission to GW impact, $\mathrm{Cu}$ leaching from bottom ash to ETs impact).

The most sensitive parameters appear to be same for all the three WtE systems: electricity recovery, $\mathrm{CO}_{2}$ emission, and $\mathrm{NO}_{\mathrm{x}}$ emission. This means that an uncertainty of their value would induce a larger variation in the final LCA result. Simultaneously, the results also help to identify potentials of further improvement. For instance, the amount of electricity recovered could be influenced by both the waste properties (caloric value) and the energy efficiency; $\mathrm{CO}_{2}$ emission is related to the waste composition (fossil carbon content); while $\mathrm{NO}_{\mathrm{x}}$ emission could be a result of selected WtE technology (gasification vs. incineration) as well as regional emission regulations.

\section{Discussion}

In this study, the Finnish gasification plant is studied since it is a 

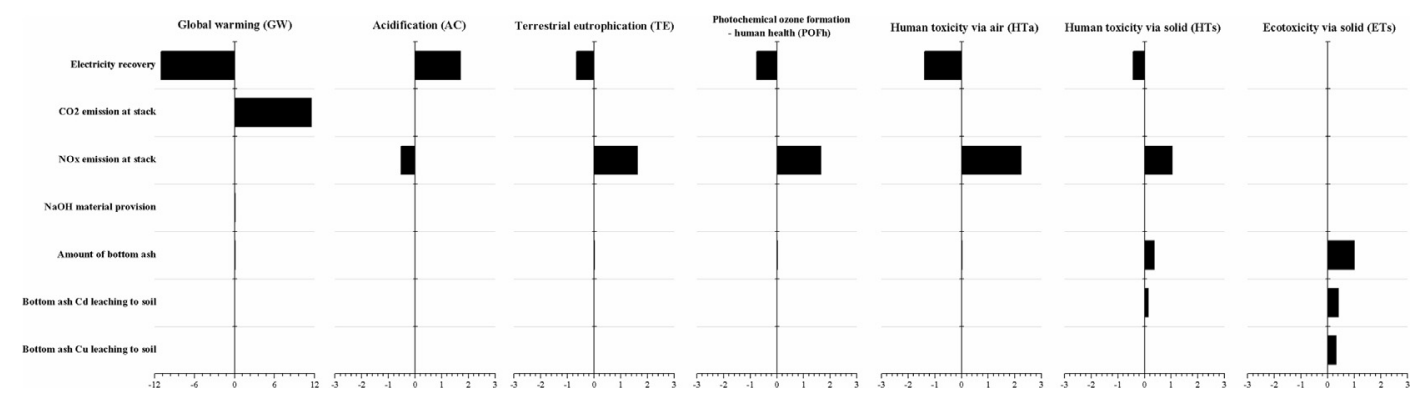

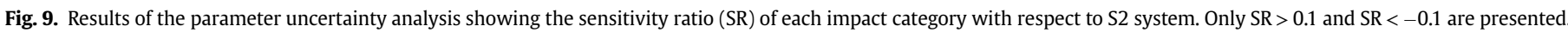

Table 8

Costs and revenues from incineration- and gasification-based WtE systems, based on survey of some literature studies.

\begin{tabular}{|c|c|c|c|c|c|c|c|c|}
\hline Technology & Feedstock & $\begin{array}{l}\text { Plant capacity } \\
(\mathrm{kt} / \mathrm{y})\end{array}$ & $\begin{array}{l}\text { Capital } \\
\text { cost }(€ / t)^{b}\end{array}$ & $\begin{array}{l}\text { Operating } \\
\text { cost }(€ / t)\end{array}$ & $\begin{array}{l}\text { Gross } \\
\text { cost }(€ / t)\end{array}$ & $\begin{array}{l}\text { Revenue } \\
(€ / t)^{c}\end{array}$ & $\begin{array}{l}\text { Net cost } \\
(€ / t)^{d}\end{array}$ & Reference \\
\hline CFB gasification + CCGT & RDF & $50-100$ & $15.0-19.2$ & $75.0-84.0$ & $90.0-103.2$ & $39.6-43.5$ & $46.5-63.6$ & (Yassin et al., 2009) \\
\hline CFB incineration & RDF & $50-100$ & $16.0-20.1$ & $65.0-82.0$ & $81.0-102.1$ & $29.7-36.4$ & $44.7-72.4$ & \\
\hline GB incineration & MSW & 136 & 11.9 & $61.1-66.9$ & $73.0-78.8$ & 26.0 & $47.0-52.8$ & \\
\hline Gasification & MSW & 45 & & & 27.9 & 25.7 & 2.2 & (Fernández-González et al., 2017) \\
\hline Incineration & MSW & 45 & & & 53.4 & 32.6 & 20.8 & \\
\hline Gasification & MSW & 750 & 2.6 & 77.8 & 80.4 & 123.1 & -42.7 & (Tan et al., 2015) \\
\hline Incineration & MSW & $750^{e}$ & 1.8 & 54.3 & 56.1 & 205.6 & -149.5 & \\
\hline GB gasification & MSW refuse & 85 & $15.3^{\mathrm{f}}$ & 52.0 & 67.3 & 43.2 & 24.1 & (Aracil et al., 2018) \\
\hline FB gasification + ICE & MSW refuse & 85 & $13.3^{\mathrm{f}}$ & 58.0 & 71.3 & 89.3 & -18.0 & \\
\hline FB gasification + ORC & MSW refuse & 85 & $7.9^{f}$ & 33.0 & 40.9 & 31.7 & 9.2 & \\
\hline GB incineration & MSW refuse & 245 & $8.9^{f}$ & 76.0 & 84.9 & 40.5 & 44.4 & \\
\hline BFB gasification + ORC & SRF & 5 & $19.4^{\mathrm{f}}$ & 75.0 & 94.4 & 48.9 & 45.5 & (Arena et al., 2015b) \\
\hline Plasma gasification + CCGT & MSW & $2250^{\mathrm{e}}$ & 17.9 & 130.3 & 148.2 & 60.3 & 87.9 & (Jadhao et al., 2017) \\
\hline Incineration & MSW & $2250^{\mathrm{e}}$ & 3.0 & 127.3 & 130.3 & 27.4 & 102.9 & \\
\hline Incineration & MSW & $50-648$ & & & $44-188$ & & $59-98$ & (Watson et al., 2018) \\
\hline Gasification & MSW & 90 & 20.4 & 32.6 & 53.0 & 90.3 & -37.3 & (Rezaei et al., 2017) \\
\hline Incineration & MSW & 90 & 21.0 & 23.8 & 44.8 & 48.8 & -4.0 & \\
\hline FB Gasification + CCGT & MSW & 341 & 6.4 & 57.6 & 64.0 & 99.1 & -35.1 & (Rizwan et al., 2018) \\
\hline Incineration & MSW & 420 & 12.3 & 24.0 & 36.3 & 22.0 & 14.3 & \\
\hline
\end{tabular}

${ }^{\text {a }}$ WtE plant uses a steam turbine (Rankine Cycle) to recover energy, if not specified. CCGT: combined cycle gas turbine; ORC: organic Rankine Cycle; ICE: internal combustion engine; BFB: bubbling fluidized bed; RDF: refuse derived fuel.

b Capital cost is calculated into per ton of waste treated over the lifetime of the plant, without taken into account discounting rate, loans or depreciation of the plant.

capital cost $(€ / \mathrm{t})=$ total capital expenditure/(plant capacity * plant life time).

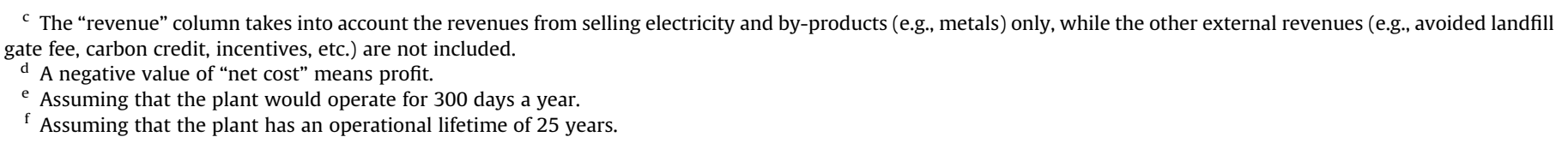

good example of a new and successful commercial case - reported to be an advanced WtE technology to compete with incineration. The comparison results reveal that gasification could serve as an environmentally preferable WtE candidate. Considering the fact that European countries bear the same emission regulation (2007/ 76/EC, see Table 6) and a similar waste composition (see Table 1), the findings obtained are suitable to reflect typical situations in Europe, namely, the Europe "as a whole".

A hypothetical calculation is conducted, assuming a complete substitution of gasification for incineration in specified countries. Applying gasification in France suggests that the current level of GW impact can be substantially reduced by $186 \mathrm{~kg} \mathrm{CO}_{2}$ per ton of MSW. Considering a total amount of 14.5 million tons of MSW incinerated in 2012, this figure equals to a net reduction of 2.7 million tons of $\mathrm{CO}_{2}$ emissions. Regarding a greater amount of MSW generated in China (73.8 million tons incinerated in 2016), the GW reduction could achieve 3.3 million tons of $\mathrm{CO}_{2}$ emissions. This evaluation, although being a relatively rough estimation, shows potential improvements of the developing WtE technology for decision-makers.

Apart from environmental and technical feasibility, economic performance is also a key factor towards the development of competitive WtE technologies. Therefore, a brief economic analysis of both incineration- and gasification-based WtE is conducted, based on survey of some literature studies. Table 8 summarizes their costs and revenues items: the "gross cost" is a sum of the plant capital and operating cost, while the "net cost" takes into account the revenues from selling electricity and by-products (e.g., metals). The data show significantly varied values from one plant to another, because the WtE plant costs are numbers depending on many specific and local factors as well as plant management, lifetime, scale, energy price, etc. (Arena et al., 2015b; Watson et al., 2018). Despite this fact, a comparable net cost is observed between incineration and gasification. Some studies (Aracil et al., 2018; Jadhao et al., 2017; Rezaei et al., 2017; Rizwan et al., 2018; Yassin et al., 2009) report that gasification plants are less costly than 
incineration, because of their higher energy recovery efficiency. An interesting fact is that gasification coupled with combined cycle gas turbine (CCGT) or internal combustion engine (IGC) performs costeffective even though they seem to increase the complexity of plant configuration. The potential benefits of gasification are also linked to its flexibility of scale, which can be built economically at smallto-medium scales (Aracil et al., 2018; Yassin et al., 2009).

Finally, regarding the LCA methodology, an attributional approach with system expansion is applied in this study. This selection is in compliance with the recommendation of Life Cycle Data System (ILCD) Handbook (Laurent et al., 2014). However, current review by Astrup et al. (2015) highlightes the considerable influence of the LCA type on the overall results. For example, we do not discuss the possible consequences (e.g. changes in energy supply system) if increasing amount of WtE plants would be operated as long-term development. This might be done by a follow-up consequential LCA using marginal energy data. Regarding the way of aggregating inventory data, a process-based LCA is used, which itemizes the process input and output data at the plant's scale along with their related supply chain. The technique, known as a bottom-up approach, is most frequent used in LCA. However, the faced difficulty is its finite definition of the boundary: certain processes would be automatically excluded creating an underestimate of the true life cycle impacts (Finnveden et al., 2009). An input-output-based LCA (IO-LCA) thus emerged owing to its nature to provide a broader and more inclusive boundary: it uses sectorial monetary transactions to connect all industry sectors at a national level, i.e., a top-down approach. Concerning the features of our data, it is thus interesting to conduct such an IO-LCA analysis, in particular, to be served as environmental policy support for decision-makers.

\section{Conclusion}

A life cycle assessment is performed to compare three WtE technologies: a gasification-based WtE plant in Finland, mechanical-grate incineration in France, and circulating fluidized bed incineration in China, considering their differences in both technological and geographic aspects. Data regarding regional MSW composition and operational parameters are used to address the variations. The gasification-based WtE shows a superior performance among the assessed systems, mainly as a consequence of the reduced process emissions, as well as the improved superheated steam to facilitate a higher energy recovery efficiency. Comparison between the two incineration cases reveals a higher environmental loading under the condition of China than that of France. The determining factors are found to be the quality of the incoming MSW, and process emission level at stack.

Sensitivity analyses have further attributed the potential advantages/disadvantages between technological and local management aspects. By assuming an identical MSW composition used in the three systems, results indicate that gasification represents a more promising WtE technology over incineration, owing to the advantages brought by syngas purification. The substituted energy structure is proven to have a large influence on the final result, i.e. the decreased environmental impacts of incineration in China and conversely increased loadings of the other two systems, which shows the importance of geographic factors in determining the effect of energy recovery. Both gasification and incineration WtE can achieve remarkable benefits by maximizing the overall energy efficiency and reducing emissions, for example optimizing for cogeneration of heat and power in areas with high heat demand. The MSW incinerators in China can be effectively improved by regulating a more stringent emission standard, as well as increasing the level of source-separated collection. Alternative important advantages can also be achieved by recycling of metals and road construction materials from the bottom ash, especially regarding the large amount of ashes generated from incinerators in France.

\section{Acknowledgments}

This project is supported by the French Centre National de la Recherche Scientifique (CNRS), the Labex SOLSTICE (Agence Nationale de la Recherche, ANR), the National Natural Science Foundation of China (No. 51676170), and the Chinese Program of Introducing Talents of Discipline to University (B08026).

\section{References}

Al-Salem, S., Evangelisti, S., Lettieri, P., 2014. Life cycle assessment of alternative technologies for municipal solid waste and plastic solid waste management in the Greater London area. Chem. Eng. J. 244, 391-402.

Aracil, C., Haro, P., Fuentes-Cano, D., Gómez-Barea, A., 2018. Implementation of waste-to-energy options in landfill-dominated countries: economic evaluation and GHG impact. Waste Manag. https://doi.org/10.1016/j.wasman.2018.03.039.

Arena, U., 2012. Process and technological aspects of municipal solid waste gasification. A review. Waste Manag. 32, 625-639.

Arena, U., Ardolino, F., Di Gregorio, F., 2015a. A life cycle assessment of environmental performances of two combustion-and gasification-based waste-toenergy technologies. Waste Manag. 41, 60-74.

Arena, U., Di Gregorio, F., De Troia, G., Saponaro, A., 2015b. A techno-economic evaluation of a small-scale fluidized bed gasifier for solid recovered fuel. Fuel Process. Technol. 131, 69-77.

Astrup, T., Moller, J., Fruergaard, T., 2009. Incineration and co-combustion of waste: accounting of greenhouse gases and global warming contributions. Waste Manag. Res. 27, 789-799.

Astrup, T.F., Tonini, D., Turconi, R., Boldrin, A., 2015. Life cycle assessment of thermal waste-to-energy technologies: review and recommendations. Waste Manag. 37, $104-115$.

Autret, E., Berthier, F., Luszezanec, A., Nicolas, F., 2007. Incineration of municipal and assimilated wastes in France: assessment of latest energy and material recovery performances. J. Hazard Mater. 139, 569-574.

Bakas, I., Laurent, A., Clavreul, J., Saraiva, A.B., Niero, M., Gentil, E., Hauschild, M.Z., 2018. LCA of solid waste management systems. In: Hauschild, M. Rosenbaum, R.K., Olsen, S. (Eds.), Life Cycle Assessment. Springer, Cham, pp. 887-926.

Beylot, A., Hochar, A., Michel, P., Descat, M., Ménard, Y., Villeneuve, J., 2016. LCA of Municipal Solid Waste Incineration in France: from Comprehensive Site-specific Data to Life Cycle Inventory Modeling.

Beylot, A., Villeneuve, J., 2013. Environmental impacts of residual Municipal Solid Waste incineration: a comparison of 110 French incinerators using a life cycle approach. Waste Manag. 33, 2781-2788.

Bisinella, V., Götze, R., Conradsen, K., Damgaard, A., Christensen, T.H., Astrup, T.F., 2017. Importance of waste composition for Life Cycle Assessment of waste management solutions. J. Clean. Prod. 164, 1180-1191.

Boesch, M.E., Vadenbo, C., Saner, D., Huter, C., Hellweg, S., 2014. An LCA model for waste incineration enhanced with new technologies for metal recovery and application to the case of Switzerland. Waste Manag. 34, 378-389.

Brander, M., 2017. Comparative analysis of attributional corporate greenhouse gas accounting, consequential life cycle assessment, and project/policy level accounting: a bioenergy case study. J. Clean. Prod. 167, 1401-1414.

Burnley, S., Coleman, T., Peirce, A., 2015. Factors influencing the life cycle burdens of the recovery of energy from residual municipal waste. Waste Manag. 39, 295-304.

Cardoen, D., Joshi, P., Diels, L., Sarma, P.M., Pant, D., 2015a. Agriculture biomass in India: Part 1. Estimation and characterization. Resour. Conserv. Recycl. 102, 39-48.

Cardoen, D., Joshi, P., Diels, L., Sarma, P.M., Pant, D., 2015b. Agriculture biomass in India: Part 2. Post-harvest losses, cost and environmental impacts. Resour. Conserv. Recycl. 101, 143-153.

Chen, D., Christensen, T.H., 2010. Life-cycle assessment (EASEWASTE) of two municipal solid waste incineration technologies in China. Waste Manag. Res. 28 (6), 508-519.

China State Environmental Protection Administration, 2014. Pollution Control Standard for Municipal Solid Waste Incineration (GB 18485-2014). China Environmental Science Press, Beijing.

Christensen, T.H., Simion, F., Tonini, D., Møller, J., 2009. Global warming factors modelled for 40 generic municipal waste management scenarios. Waste Manag. Res. 27, 871-884.

Coelho, L.M.G., Lange, L.C., 2018. Applying life cycle assessment to support environmentally sustainable waste management strategies in Brazil. Resour. Conserv. Recycl. 128, 438-450.

Dabo, D., Badreddine, R., De Windt, L., Drouadaine, I., 2009. Ten-year chemical evolution of leachate and municipal solid waste incineration bottom ash used in a test road site. J. Hazard Mater. 172, 904-913. 
Directive Waste Framework, 2006. Directive 2006/12/EC of the European parliament and of the Council of 5 April 2006 on Waste, vol. 144. Off. J. Eur. Union.

Evangelisti, S., Lettieri, P., Borello, D., Clift, R., 2014. Life cycle assessment of energy from waste via anaerobic digestion: a UK case study. Waste Manag. 34, 226-237.

Evangelisti, S., Tagliaferri, C., Clift, R., Lettieri, P., Taylor, R., Chapman, C., 2015. Life cycle assessment of conventional and two-stage advanced energy-from-waste technologies for municipal solid waste treatment. J. Clean. Prod. 100, 212-223.

Fernández-González, J., Grindlay, A., Serrano-Bernardo, F. Rodríguez-Rojas, M. Zamorano, M., 2017. Economic and environmental review of Waste-to-Energy systems for municipal solid waste management in medium and small municipalities. Waste Manag. 67, 360-374.

Finnveden, G., Hauschild, M.Z., Ekvall, T., Guinée, J., Heijungs, R., Hellweg, S., Koehler, A., Pennington, D., Suh, S., 2009. Recent developments in life cycle assessment. J. Environ. Manag. 91, 1-21.

Fruergaard, T., Astrup, T., 2011. Optimal utilization of waste-to-energy in an LCA perspective. Waste Manag. 31, 572-582.

Havukainen, J., Heikkinen, S., Horttanainen, M., 2016. Possibilities to Improve the Share of Material Recovery of Municipal Solid Waste in Finland. LUT Scientific and Expertise Publications/Tutkimusraportit-Research Reports.

Hong, J., Chen, Y., Wang, M., Ye, L., Qi, C., Yuan, H., Zheng, T., Li, X., 2017. Intensification of municipal solid waste disposal in China. Renew. Sustain. Energy Rev. 69, 168-176.

Hoornweg, D., Bhada-Tata, P., 2012. What a Waste: a Global Review of Solid Waste Management. The World Bank, Washington DC.

Ikhlayel, M., 2018. Development of management systems for sustainable municipal solid waste in developing countries: a systematic life cycle thinking approach. J. Clean. Prod. 180, 571-586.

ISO, 2006. ISO 14040: Environmental Management-life Cycle Assessment-principles and Framework, second ed. ISO, Geneva.

Jadhao, S.B., Shingade, S.G., Pandit, A.B., Bakshi, B.R., 2017. Bury, burn, or gasify: assessing municipal solid waste management options in Indian megacities by exergy analysis. Clean Technol. Environ. Policy 19, 1403-1412.

Kourkoumpas, D.-S., Karellas, S., Kouloumoundras, S., Koufodimos, G., Grammelis, P. Kakaras, E., 2015. Comparison of waste-to-energy processes by means of life cycle analysis principles regarding the global warming potential impact: applied case studies in Greece, France and Germany. Waste Biomass Valorization 6, 605-621.

Lahti Energia, http://www.lahtigasification.com/.

Laohalidanond, K., Chaiyawong, P., Kerdsuwan, S., 2015. Municipal solid waste characteristics and green and clean energy recovery in Asian megacities. Energy Procedia 79, 391-396.

Laurent, A., Clavreul, J., Bernstad, A., Bakas, I., Niero, M., Gentil, E., Christensen, T.H., Hauschild, M.Z., 2014. Review of LCA studies of solid waste management systems-Part II: methodological guidance for a better practice. Waste Manag. 34, 589-606.

Lausselet, C., Cherubini, F., del Alamo Serrano, G., Becidan, M., Strømman, A.H., 2016 Life-cycle assessment of a Waste-to-Energy plant in central Norway: current situation and effects of changes in waste fraction composition. Waste Manag. $58,191-201$

Leckner, B., 2015. Process aspects in combustion and gasification Waste-to-Energy (WtE) units. Waste Manag. 37, 13-25.

Lombardi, L., Carnevale, E., Corti, A., 2015. A review of technologies and performances of thermal treatment systems for energy recovery from waste. Waste Manag. 37, 26-44.

Lu, J.W., Zhang, S., Hai, J., Lei, M., 2017. Status and perspectives of municipal solid waste incineration in China: a comparison with developed regions. Waste Manag. 69, 170-186.

McDougall, F.R., White, P.R., Franke, M., Hindle, P., 2008. Integrated Solid Waste Management: a Life Cycle Inventory, second ed. Blackwell Science Ltd., UK. ed.

Mengibar Guerrero, N., 2017. Utilization of Concrete and Ash Waste in Geotechnical Construction: Legislation, Methods and Analysis Requirements in Finland and Spain. Lahti University of Applied Sciences.

Mian, M.M., Zeng, X., Nasry, A.a.N.B., Al-Hamadani, S.M., 2016. Municipal solid waste management in China: a comparative analysis. J. Mater. Cycles Waste $1-9$.

Nabavi-Pelesaraei, A., Bayat, R., Hosseinzadeh-Bandbafha, H., Afrasyabi, H., Chau, K.$\mathrm{w}$, 2017. Modeling of energy consumption and environmental life cycle assessment for incineration and landfill systems of municipal solid waste management-A case study in Tehran Metropolis of Iran. J. Clean. Prod. 148,
$427-440$

Nasrullah, M. Vainikka, P. Hannula, J., Hurme, M., Kärki, J., 2015. Mass, energy and material balances of SRF production process. Part 3: solid recovered fuel produced from municipal solid waste. Waste Manag. Res. 33, 146-156.

Nzihou, A., Themelis, N.J., Kemiha, M., Benhamou, Y., 2012. Dioxin emissions from municipal solid waste incinerators (MSWIs) in France. Waste Manag. 32, 2273-2277.

Panepinto, D., Tedesco, V., Brizio, E., Genon, G., 2015. Environmental performances and energy efficiency for MSW gasification treatment. Waste Biomass Valorization 6,123-135.

Phillips, K., Longhurst, P.J., Wagland, S.T., 2014. Assessing the perception and reality of arguments against thermal waste treatment plants in terms of property prices. Waste Manag. 34, 219-225.

Rezaei, M., Ghobadian, B., Samadi, S.H., Karimi, S., 2017. Electric power generation from municipal solid waste: a techno-economical assessment under different scenarios in Iran. Energy 152, 46-56.

Rizwan, M., Saif, Y., Almansoori, A., Elkamel, A., 2018. Optimal processing route for the utilization and conversion of municipal solid waste into energy and valuable products. J. Clean. Prod. 174, 857-867.

Rocco, M.V., Di Lucchio, A., Colombo, E., 2017. Exergy life cycle assessment of electricity production from waste-to-energy technology: a hybrid input-output approach. Appl. Energy 194, 832-844.

Savelainen, J., Isaksson, J., 2015. Kymijärvi II Plant: High-efficiency Use of SRF in Power Production through Gasification, Report by Lahti Energy Ltd and Metso Power Oy (Finland).

Sevigné-Itoiz, E., Gasol, C.M., Rieradevall, J., Gabarrell, X., 2015. Methodology of supporting decision-making of waste management with material flow analysis (MFA) and consequential life cycle assessment (CLCA): case study of waste paper recycling. J. Clean. Prod. 105, 253-262.

Shehzad, A. Bashir, M.J., Sethupathi, S., 2016. System analysis for synthesis gas (syngas) production in Pakistan from municipal solid waste gasification using a circulating fluidized bed gasifier. Renew. Sustain. Energy Rev. 60, 1302-1311.

Singh, A., Olsen, S.I., Pant, D., 2013. Importance of life cycle assessment of renewable energy sources. In: Singh, A., Pant, D., Olsen, S.I. (Eds.), Life Cycle Assessment of Renewable Energy Sources. Springer, London, pp. 1-11.

Tan, S.T., Ho, W.S., Hashim, H., Lee, C.T., Taib, M.R., Ho, C.S., 2015. Energy, economic and environmental (3E) analysis of waste-to-energy (WTE) strategies for municipal solid waste (MSW) management in Malaysia. Energy Convers. Manag. 102, 111-120.

The Commission of the European Communities, 2007. Commission Directive 2007/ 76/EC of 20 December 2007, Amending Council Directive 91/414/EEC to include Fludioxonil, Clomazone and Prosulfocarb as Active Substances. Office Journal of the European Union.

The European Parliament and the Council of European Communities, 2008. Directive 2008/98/EC of the European parliament and of the Council of 19 November 2008 on waste and repealing certain directives. Off. J. Eur. Union L 312, 3-30.

Tisserant, A., Pauliuk, S., Merciai, S., Schmidt, J., Fry, J., Wood, R., Tukker, A., 2017. Solid waste and the circular economy: a global analysis of waste treatment and waste footprints. J. Ind. Ecol. 21, 628-640.

Turner, D.A., Williams, I.D., Kemp, S., 2016. Combined material flow analysis and life cycle assessment as a support tool for solid waste management decision making. J. Clean. Prod. 129, 234-248.

U.S. Energy Information Administration (EIA), 2012. International Energy Statistics 2012. http://www.eia.gov/.

Wang, H., Wang, L., Shahbazi, A., 2015. Life cycle assessment of fast pyrolysis of municipal solid waste in North Carolina of USA. J. Clean. Prod. 87, 511-519.

Watson, J., Zhang, Y., Si, B., Chen, W.-T., de Souza, R., 2018. Gasification of biowaste: a critical review and outlooks. Renew. Sustain. Energy Rev. 83,1-17.

Yassin, L., Lettieri, P., Simons, S.J., Germanà, A., 2009. Techno-economic performance of energy-from-waste fluidized bed combustion and gasification processes in the UK context. Chem. Eng. J. 146, 315-327.

Yay, A.S.E., 2015. Application of life cycle assessment (LCA) for municipal solid waste management: a case study of Sakarya. J. Clean. Prod. 94, 284-293.

Zaman, A., 2013. Life cycle assessment of pyrolysis-gasification as an emerging municipal solid waste treatment technology. Int. J. Environ. Sci. Technol. 10, 1029-1038.

Zhou, H., Meng, A., Long, Y., Li, Q., Zhang, Y., 2014. An overview of characteristics of municipal solid waste fuel in China: physical, chemical composition and heating value. Renew. Sustain. Energy Rev. 36, 107-122. 